PART 1

\title{
Networks
}


besberger, Paul Arblaster, Mario Infelise, André Belo, Noah Moxham, Carmen Espejo, and Joad Raymond - 9789004277199 Downloaded from Brill.come4/26/2023 12:33:12AM via free access 


\title{
European Postal Networks
}

\author{
Nikolaus Schobesberger, Paul Arblaster, Mario Infelise, André Belo, \\ Noah Moxham, Carmen Espejo and Joad Raymond
}

During the early sixteenth century state postal routes, based on a sequence of horses ridden by a single rider across a series of organised stages, were developed across Europe and were progressively transformed into public services. Postal communication was fundamental to European news, and though they were by no means the only basis of communication they formed the essential spine to news networks. ${ }^{1}$ We have two working assumptions: the first, that the penetration of avvisi into the public culture of early-modern Europe (i.e. beyond official communications) depended on the development of accessible postal services. The second is that (relatively) predictable public postal deliveries, which developed out of state administrative needs and manuscript culture, including manuscript news, were a precondition for the development of a (relatively) periodic newspaper press. Once newspapers were established, they could draw in communications from other types of network connection (merchants, churches and monasteries, booksellers, diplomatic couriers, soldiers, travellers, ships' captains, and so on), but to be widely established in the first place they needed reliable public posts, bringing correspondence from a number of newswriting centres elsewhere. In this article we sketch the various postal systems that transversed Europe, and, crucially, how they were interconnected.

\section{The Holy Roman Empire}

Until the 1490s the communication network in the Holy Roman Empire was built up by courier services of merchant families, cities, aristocrats and sovereigns. All these services were inaccessible to the wider public. Due to the needs

1 Paul Arblaster, 'Posts, Newsletters, Newspapers: England in a European system of communications', in News Networks in Seventeenth Century Britain and Europe, ed. Joad Raymond (London: Routledge, 2006), pp. 19-34, and From Ghent to Aix: How They Brought the News in the Habsburg Netherlands, 1550-1700 (Leiden: Brill, 2014); Wolfgang Behringer, Im Zeichen des Merkur: Reichspost und Kommunikationsrevolution in der frühen Neuzeit (Göttingen: Vandenhoeck \& Ruprecht, 2003).

(C) NIKOLAUS SCHOBESBERGER ET AL., 2016 | DOI 10.1163/9789004277199_003

This is an open access chapter distributed under the terms of the Creative Commons Attribution-

Noncommercial-NoDerivatives 3.o Unported (CC-BY-NC-ND 3.0)License.spejo, and Joad Raymond - 9789004277199 
of the Habsburg dynasty for communication over longer distances, primarily for the gathering of political news for the court and for administration, but additionally to serve the needs of the emerging merchant communities and cities, the postal system in the Holy Roman Empire developed very rapidly in the last decades of the fifteenth century and the beginning of the sixteenth century.

The reasons for establishing an Imperial post were the emerging needs of the Habsburgs for an efficient method of communication after the acquisitions of the Burgundian and later the Spanish Inheritance. In particular the emperor, Charles v, who reigned over the Spanish kingdoms with their colonies, the Low Countries, southern Italy, Lombardy and the Holy Roman Empire, was very interested in developing a fast and efficient information system.

Maximilian I first established an Imperial postal system in 1490, immediately after he gained control over the county of Tyrol. The management of this Imperial post was given to the Taxis family, originating from Bergamo, whose members had rich experiences in the courier services of the pope and of Venice. They built up a system of posting houses between Innsbruck and Brussels, the residence of Maximilian's son Philipp. On this main route the running time was a mere five days (six in winter).

The main route went from Brussels via Augsburg to Innsbruck then across the Alps to northern Italy, where the Imperial post connected with the postal systems of the Italian states. The first headquarters of the Imperial post was Innsbruck, the favoured residence of Emperor Maximilian I. In 1501 the postal centre moved to Brussels and was subordinated to the Spanish crown. In 1505 Franz von Taxis and Philip I of Spain signed a contract, in which the post was awarded the status of an independent service company. In the second Neerlando-Spanish postal contract of 1516, the Taxis gained control over the postal system in the Italian territories of the Spanish crown. In 1530 Emperor Charles v appointed Johann Baptist von Taxis to the rank of postmastergeneral over all his territories, including the Holy Roman Empire. This led the way from the Spanish Taxis-post to the future Imperial post. For financial reasons, the Taxis began, in the first decade of the sixteenth century at the latest, not only to transport the dynastic and administrative post of the Habsburgs, but also to offer their service to other groups of customers. This meant that not only the major merchant families, like the Fuggers and the Welsers from Augsburg, but also cities, secular and clerical authorities, and private persons could make use of the postal service. They had to pay a postal charge for the transport of the mail.

In this way the dynastic transport service changed its character into a service company, accessible to everyone, with a defined scale of charges and regular traffic. By the 1530 at the latest the postal service had weekly intervals. 
The pre-existing courier services of cities, merchants and aristocrats in the Holy Roman Empire connected to the postal route from Brussels to Innsbruck. News could circulate more quickly than before and the space between the North Sea and the Mediterranean was shrinking.

In the second half of the sixteenth century other Princes of the Holy Roman Empire installed their own messenger relay services, which were only for their private needs, not for the public. Correspondingly, during the sixteenth century the major merchant cities built a network of courier services along the main trading routes in the Empire. The cities of Augsburg, Nuremberg, Frankfurt, Cologne, Leipzig and Hamburg, which were (except for Augsburg and later Cologne) not connected to the Imperial post, were connected by their own services. For example the Nuremberg courier connected the cities of Nuremberg and Hamburg and was the main communication line to the Hanseatic states of northern Germany. A letter from Cologne to Hamburg would have been transported by the Cologne courier to Frankfurt, by the Frankfurt courier to Nuremberg and by the Nuremberg courier to Hamburg.

The post intensified and accelerated communication in every way, for instance through the sending of letters and news, the transportation of passengers, and the cashless transactions via bills of exchange. On the main route between Brussels and Innsbruck the distances between posting houses were reduced from 35 to $22 \mathrm{~km}$ and in the first third of the seventeenth century to 15 $\mathrm{km}$. Until the implementation of the mail coach in the late seventeenth century, private persons could use the service of the posting houses for hiring and changing horses. The first evidence for the use of this service dates from 1515 .

As the payments from the Spanish Habsburgs were notoriously slow and incomplete, the Taxis post focused on private transportation. Brussels remained the main centre of the Taxis post and the seat of the general postmaster. In the Holy Roman Empire the 'Spanish' post was increasingly seen as an aberration. This intensified in the second half of the sixteenth century due to the national bankruptcies of Spain and the Dutch War of Independence, starting in 1568. In 1577 the international postal system of the Taxis collapsed, after the postmaster-general Leonhard I von Taxis lost his property during the Dutch rebellion and left the Netherlands. During this postal crisis the local courier services of cities and merchants filled the void in communication and information. The reformation of the post by Emperor Rudolf II put an end to the postal crisis. In 1595 Leonhard von Taxis was declared the General high postmaster of the Holy Roman Empire. In 1597 Rudolf II declared the postal transportation in the Empire to be an Imperial prerogative, which was granted to the Taxis family as a fiefdom. It was forbidden, under threat of severe penalties, for other courier services to offer the transportation of post and to use the post horn. The aim of this regulation was to build a monopoly of postal 
transportation under the control of the imperial administration. The newly christened 'Reichspost' was to be made profitable by eliminating its private competitors. Despite the forbidding of private postal services, the courier systems of the cities and merchants were necessary to ensure service to the whole Empire till the nineteenth century.

The monopoly of the centralised Taxis post in postal transportation made governmental censorship possible, which was first used on a large scale during the 1640 .

Beginning in around the last quarter of the sixteenth century, the main postal route from Antwerp to Innsbruck and Italy was complemented by new routes. In this way a postal network was formed. New postal stations were established in the major cities Cologne (1577), Frankfurt (1598), Hamburg (1616), Erfurt (1616), Nuremberg (1617) and Regensburg (1618). The founding of these postal houses was necessary after the prohibition of private postal services. Between 1604 and 1615 a route from Cologne via Frankfurt and Nuremberg to Prague was built. Just before the beginning of the Thirty Years War, the post house in Frankfurt replaced Augsburg as the most important centre in the German postal network. German princes besides the Emperor also built up their own postal systems in their territories. Especially during the Thirty Years War a lot of German territories-especially in the northern parts of the Empire, that fell under the Swedish sphere of influence-established postal networks after the model of the Taxis Reichspost.

In fact the first territorial postal system was the court post of the Habsburgs in the Austrian, Bohemian and Hungarian territories, which was already in place at the beginning of the sixteenth century and also managed by the Taxis family. In 1623 the management was transferred to the Styrian Paar family. Like the Reichspost, the Austrian Post was initially licensed to transport only the mails of the Habsburgs, the court and the administration. The 'court Post' was connected to the Reichspost by two routes, one from Vienna to Innsbruck, the other from Prague to Augsburg, which were established in the $1520 s$.

During the Thirty Years War the rulers of Brandenburg, Brunswick-Lüneburg, Saxony and Hesse-Kassel licensed their own postal systems, which were loosely connected to the Reichspost. In 1648 Elector Frederick William of Brandenburg ordered the building of a Brandenburgian postal system. The first route connected Memel-Berlin-Kleve with branches to Amsterdam, Hamburg, Stettin, Leipzig, Breslau and Warsaw. The Brandenburg post was organised as a governmental enterprise under the control of the Brandenburg state council.

In 1658 the fiefdom of the post to the Taxis family (Thurn and Taxis since 1650) was renewed after the election of Emperor Leopold I. First the postal rights of the German territorial princes were respected, until 1660, when Leopold, who was very much interested in an imperially controlled postal 
monopoly, prohibited all territorial posts. Brandenburg, Brunswick and Hesse, which all had their own territorial postal services, joined with Sweden in their rejection of the authority of the Reichspost. The following decades were dominated by competitions between the Reichspost and the territorial services, which were also in competition with each other. Several postal routes were operated by two or more postal services. For example on the route AachenCologne-Frankfurt-Leipzig the Brandenburg Post and the Taxis Reichspost were in direct competition.

In 1681 the Elector of Saxony took control of all postal services in his lands and ordered the building of a territorial system as well. The differences between the Brandenburg and the Saxony posts lasted until 1699. As it was politically impossible for Leopold I to enforce the claim of the Reichspost-monopoly for the whole empire a mixed system was established, whereby the northern territories enjoyed their own system and the southern parts of Germany came under control of the Reichspost. This plurality of services persisted until $1700{ }^{2}$

\section{The Netherlands and Further Afield}

Both the Northern Netherlands (the Dutch Republic) and the Southern (Habsburg) Netherlands had dense networks of civic carriers and (especially in the North) barge and ferry services for the internal communications between various larger and smaller towns. ${ }^{3}$ One source that opens a window on to the density of carrier networks in the Southern Netherlands is the overview drawn up around 1618 by Father Damiaan Pletz, secretary to the provincial of the Flemish Province of the Capuchin order, showing the various fortnightly,

2 For sources for the Holy Roman Empire, see Johannes Arndt and Esther-Beate Körber, eds., Das Mediensystem im Alten Reich der Frühen Neuzeit (1600-1750) (Göttingen: Vandenhoeck \& Ruprecht, 2010); Oswald Bauer, Zeitungen vor der Zeitung. Die Fuggerzeitungen (1568-1605) und das frühmoderne Nachrichtensystem (Berlin: Oldenbourg Akademieverlag, 2011); Behringer, Im Zeichen des Merkur, and 'Fugger und Taxis. Der Anteil Augsburger Kaufleute an der Entstehung des europäischen Kommunikationssystems', in Augsburger Handelshäuser im Wandel des historischen Urteils, ed. Johannes Burkhardt (Berlin: Akademie Verlag, 1996), pp. 241-8; Thomas Schröder, 'The Origins of the German Press', in The Politics of Information in Early Modern Europe, ed. Brendan Dooley and Sabrina A. Baron (London: Routledge, 2001), pp. 123-50; Cornel Zwierlein, Discorso und Lex Dei. Die Entstehung neuer Denkrahmen im 16. Jahrhundert und die Wahrnehmung der französischen Religionskriege in Italien und Deutschland (Göttingen: Vandenhoeck \& Ruprecht, 2006).

3 On connections by inland waterway see Jan de Vries, Barges and Capitalism: Passenger Transportation in the Dutch Economy, 1632-1839 (Amsterdam: Amsterdam University Press, 2006). 
weekly, twice- or thrice-weekly, and sometimes daily services available between the towns in which there was a Capuchin house. ${ }^{4}$ These services ranged from licensed carriers to poulterers and yeastmen who carried messages on their regular rounds. This was a working document for a man who needed to communicate with the houses of his order, so it omits all towns not on the Capuchin network except for the ports Nieuwpoort and Dunkirk (important for their shipping connections).

Another partial source, listing only those carriers with services from Ghent, can be found in an almanac printed in Ghent for the year $1636 .{ }^{5}$ Frequencies again varied from fortnightly (to Hondschoote), through weekly (to Paris, to London), to two or three times per week (to most towns in Flanders), and even daily (to Bruges, to Brussels and to Antwerp).

By 1541 Antwerp was connected to the main imperial post when a Taxis branch office opened in the city; Brussels was already the headquarters from which the Taxis dynasty ran the imperial posts. The main international post road, the backbone of Europe's postal communications, was from Brussels to Augsburg to Trent, there splitting for Venice, for Rome, and for Milan. ${ }^{6}$ There was daily service between Brussels and Antwerp, which was the point at which the Taxis post connected with the Antwerp civic carrier system that linked to London and to the northern Netherlands. ${ }^{7}$

The fullest contemporary description of the ordinary posts of Europe is provided by Ottavio Codogno, deputy postmaster general of the state of Milan, in his Nuovo itinerario delle poste per tutto il mondo, first printed in 1608 and much reprinted, sometimes under the title Compendio delle poste (see Figure 2.2). Codogno explains that those wishing to write beyond the northern confines of the ordinary public posts could do so by having their letters forwarded through Antwerp's merchant carrier networks:

Should you wish to write to the States of Holland, that is The Hague, Dordrecht, Haarlem, Rotterdam, Delft, Leiden, Amsterdam, Utrecht, Gelre,

4 P. Hildebrand, 'Vlaamse boden in 1618-1619', Bijdragen tot de Geschiedenis, 32 (1949), pp. $43^{-7}$.

5 Joos de Schepere, Almanach van't Schrickel-jaer ons Heeren M.DC.XXXVI. Gemaeckt ende gecaluleert op den Meridiaen der vermaerde stadt van Gent met harre omliggende Provincien (Ghent, 1636). Available online at:<books.google.com/books?id=_s4WAAAAQAAJ/> [21/4/15].

6 Jan Albert Van Houtte, 'Les postes dans les Pays-Bas Méridionaux sous la maîtrise des Tour et Taxis', in De post van Thurn und Taxis. La poste des Tour et Taxis. 1489-1794, ed. Luc Janssens and Marc Meurrens (Brussels: Algemeen Rijksarchief, 1992).

7 M. Coppens and P. De Gryse, 'De Antwerpse stadsboden. Een bijdrage tot de kennis van de lagere ambtenarij in de 17 de eeuw', in Liber alumnorum Karel Van Isacker S.J. (Bijdragen tot de Geschiedenis 63; 1980), pp. 151-217, at $15^{2}$. 
Zutphen, Arnhem and Nijmegen, or further to Lübeck, Rostock, Wismar, Stralsund and Novgorod, do so by way of the merchants of Antwerp. ${ }^{8}$

This 'merchant post' was licensed by the city and based at the Antwerp Exchange. The combination in Antwerp of a Taxis post office and the extensive system of merchant carriers made the city one of the most important postal interchanges north of the Alps.

Older corporate bodies (such as monasteries and universities) had dedicated messengers with some sort of postal privilege, but these were not open to the general public; some letters continued to be sent by private couriers, by ships' captains, or through trade connections that were not strictly postal, and even by chance travellers; while government bodies made frequent use of special couriers. The systems that were both regular and public were the civic (or merchant) carriers, licensed by the cities from which they operated, and the royal posts run by the Taxis family.

In the first half of the seventeenth century Amsterdam's main international carrier services were provided from Antwerp, Cologne and Hamburg. In the second half of the century Amsterdam developed its own civic control of the Dutch end of these connections, which were eventually merged and nationalised in the eighteenth century. ${ }^{9}$ There were also services between Antwerp and Rotterdam. Attempts to establish Dutch postal connections to England in the second half of the seventeenth century were complicated by the Anglo-Dutch Wars. A service from Rotterdam to Dover, begun in 1660 , failed to survive past $1665,{ }^{10}$ while an Amsterdam service, with a packet boat between Harwich and Hellevoetsluis, ${ }^{11}$ survived (with interruptions) but became a point of contention, litigation and lobbying between Amsterdam and Rotterdam well into the eighteenth century. ${ }^{12}$ The

“Et volendo scrivere per li Stati d'Hollanda, cioè per Haia, Dordrech, Haerlem, Roterdam, Delft, Leiden, Olanda [sic], Amsterdam, Utrech, Della Gheldria, Zutfen, Armen [sic], \& Nimega, \& anco per Lubecco, Rostoc, Vismar, Stralsunda, e Novogardia, inviatele a' negotianti d'Anversa". Codogno, Compendio delle poste (Milan, 1623), p. 428.

9 J.C. Overvoorde, Geschiedenis van het Postwezen in Nederland vóór 1795 met de voornaamste verbindingen met het buitenland (Leiden: Sijthoff, 1902), pp. 146-7.

10 Overvoorde, Geschiedenis van het Postwezen, p. 251.

11 J.C.W. Le Jeune, Het Brieven-postwezen in de Republiek der Vereenigde Nederlanden (Utrecht: Kemink en Zoon, 1851), p. 106.

12 Herman Bots and Joris Wiersinga, 'Brieven en aandelen. Het Amsterdamse postnetwerk en de integratie van kapitaalmarkten in de 18e eeuw', Leidschrift, 13:2 (1998), pp. 97-115, at 99-103; Generalen Index op de Registers der Resolutien van de Heeren Staten van Hollandt ende West-Vrieslandt for 1687-1700 and 1701-13, s.v. 'Posteryen', 'Post', 'Postmeesters'. 
Dutch posts to Hamburg were a similar bone of contention between the two cities. ${ }^{13}$

During the second phase of the Eighty Years War (1621-48) there were packet boats from Middelburg and Vlissingen to Rouen and Calais, to avoid passage through the Southern Netherlands, but these could fall victim to Dunkirk privateering. Military activities and marauding soldiers could disrupt other parts of the network in various ways. ${ }^{14}$ The rivalry in Holland between the merchants of Rotterdam and of Amsterdam was mirrored in the South by the rivalry between the Taxis postmaster general in Brussels and the Taxis postmaster of Antwerp early in the century, as well as between the Taxis system and the civic carrier system through mid-century. ${ }^{15}$ Central government insistence that civic carriers defer to the Taxis posts was a blow to Antwerp's position as the linchpin of the carrier and postal systems, leading to protests and civil disobedience that verged on rebellion, and that were put down by military force. ${ }^{16}$ In the second half of the seventeenth century, the Taxis postmaster general in Brussels co-operated with the postmaster of Rotterdam to cut Antwerp out of the main link between Holland and Paris, ending the city's importance to Europe's postal infrastructure. ${ }^{17}$

\section{Italy}

Under Giangaleazzo Sforza, Duke of Milan from 1378 to 1402, there was a radical reorganisation of the postal system in a modern sense. The main routes

13 E.A.B.J. ten Brink, 'Een langdurige controverse tussen Amsterdam en Rotterdam over de postverbinding met Hamburg', Economisch-historisch jaarboek, 32 (1967-8), pp. 235-68.

14 J.A. Worp, ed., De Briefwisseling van Constantijn Huygens (16o8-1687), vol. 1 (The Hague: Martinus Nijhoff, 1911), pp. 308, 368; ibid., vol. 3 (The Hague: Martinus Nijhoff, 1914), pp. 19, 243; Maarten Coppens, Piet De Gryse, James Van Der Linden and Leo De Clercq, De Post te Antwerpen van aanvang tot 1793 (Antwerp: Pandora, 1993), p. 101.

15 Overvoorde, Geschiedenis van het Postwezen, pp. 38-40.

16 Birgit Houben, 'Violence and Political Culture in Brabant', in Hoge rechtspraak in de oude Nederlanden, ed. Hugo de Schepper and René Vermeir (Maastricht: Shaker Publishing, 2006), pp. 23-49. The official account of the settlement of the conflict was published in Brussels in 1659 as Acten van Accommodement van de ongheregeltheden Veroorsaeckt binnen der Stadt Antwerpen, door resistentien van de dekens ende ambachten Teghens d'Executie van den Vonnisse by den Rade van Brabandt ghewesen op het stuck van de Posterye (Acts of accommodation of the irregularities caused within the city of Antwerp by the resistance of the deans and guilds against the execution of the sentence of the Council of Brabant regarding the posts). 
were divided into stages called poste that were covered by professional post riders with in-depth knowledge of the roads who could even travel by night. During this period the postal system became a public service with fixed departure times and charges that were known to all and accessible to anyone who could afford it, regardless of rank or class. ${ }^{18}$ During the fifteenth and sixteenth centuries, this system gradually extended to all of northern Italy and central and western Europe, becoming - as pointed out by Wolfgang Behringer-'a crucial agent of change' that distinguished Europe from contemporary Asia where such communication networks were the exclusive purview of rulers. ${ }^{19}$

Thus the final decades of the fourteenth century saw the introduction of wide-range postal services with regular public dispatches and courses. In 1395 the Milanese agent of the Datini company wrote that every Sunday a courier would leave for Venice and Bruges, and that another rider would stop off on his way from Lucca to Paris. ${ }^{20}$ These postal services were run by private entrepreneurs or princes with the aim of providing an efficient and reliable service along constantly expanding routes; post sent from Milan took 26 days to reach London, 16 days to Paris, 18 to Barcelona, 11 to Rome and 4 to Venice..$^{21}$ The service continued to improve steadily throughout the fifteenth century, and by the time the Taxis family from Bergamo obtained the contract for the Imperial postal services in the early 1500 , tried and tested models would have been available to them. In the meantime other leading Italian entrepreneurs had also invested in this sector, harnessing consolidated organisational capacities and networks of relationships, as in the case of Sebastiano Montelupi who was appointed in 1568 by the King of Poland to set up a postal service between Venice and Krakow. ${ }^{22}$ At the time all the major European cities had official post

18 Luciana Frangioni, Milano fine Trecento. Il Carteggio milanese dell'Archivio Datini di Prato (Firenze: OpusLibri, 1994), pp. 84-112.

19 Wolfgang Behringer, 'Communications Revolutions: A Historiographical Concept', German History, 24.3 (2006), pp. 333-74.

$20 \quad$ Frangioni, Milano fine Trecento, p. 87.

21 Federigo Melis, 'Intensità e regolarità nella diffusione dell'informazione economica generale nel Mediterraneo e in Occidente alla fine del Medioevo', in Histoire économique du monde méditerranéen 1450-1650. Mélanges en l'honneur de Fernand Braudel, vol. 1 (Paris: Privat, 1973), pp. 389-424; Luciana Frangioni, Organizzazione e costi del servizio postale alla fine del Trecento (Prato: Istituto di studi storici postali, 1984); C. Fedele, M. Gallenga, 'Per servizio di Nostro signore': Strade, corrieri e poste dei papi dal medioevo al 1870 (Prato: E. Mucchi editore, 1988).

22 Rita Mazzei, Itinera mercatorum. Circolazione di uomini e beni nell'Europa centro-orientale (Lucca: Pacini Fazzi, 1999), p. 124. 
offices to handle and forward correspondence. There was also a network of postal stations at fixed intervals on the main routes where couriers could change their horses, leading to more regular delivery times, and clearly defined routes and exchange nodes.

In Italy, in the sixteenth and seventeenth centuries, the system focused on a central axis heading northwards from Rome towards Flanders. Urban centres of varying importance were all connected to this axis-bearing in mind that the Italian peninsula featured both states of European importance along with a series of more or less independent minor courts like the duchies of Mantua and Parma, the Republic of Lucca and many more fiefs aiming for capital status that needed to maintain links with the larger European network. There were a number of crucial nodes, like Rome, Venice and Milan, along with secondary nodes that were nonetheless important for the regular flow of information, like Naples, Genoa, Turin and Florence.

One of the key nodes in the seventeenth century was Rome, which had permanent links to Naples, the transit node for couriers from southern Italy, Sicily and Lecce/Otranto. Couriers from Lecce/Otranto transported letters from Corfu, from the entire Greek area and from Constantinople. ${ }^{23}$ Correspondence from the capital of the Ottoman Empire also reached Rome via the Ragusa (Dubrovnik) to Ancona route. ${ }^{24}$ The ordinari couriers travelling northwards from Rome headed for Genoa, Florence, Bologna and Ancona-Venice.

Venice not only had fairly frequent links to the minor centres in northern Italy, it also sent correspondence by ordinari couriers to Milan then via Genoa to Spain or via Turin to Lyon and France. Another important route headed north along the Trent road via the Brenner Pass and Augsburg for Germany and Flanders. The Vienna route via Gorizia and Graz was also very important. There was also a sea route going from Venice to Cattaro (Kotor), a Venetian port on the southern Dalmatian coast, and via Ragusa (Dubrovnik) to the Balkans and Constantinople, which was in turn a key node for correspondence from the entire Middle Eastern and Asian area.

Italy's third nodal point was Milan, which had connections to all major Italian centres, and couriers leaving for Flanders via Cologne, and for Prague via Trent, Munich and Regensburg. The system overall was consolidated and highly efficient, and from 1608 there were handbooks explaining in great detail

23 On the postal routes see Ottavio Codogno, Nuovo itinerario della poste per tutto il mondo (Milan, 1608).

24 Ivan Dujčev, Avvisi di Ragusa. Documenti sull'Impero turco nel sec. e sulla guerra di Candia (Rome: Pont. institutum orientalium studiorum, 1935); Luciano De Zanche, Tra Costantinopoli e Venezia. Dispacci di stato e lettere di mercanti dal Basso Medioevo alla caduta della Serenissima (Prato: Istituto di Studi Storici Postali, 200o). 


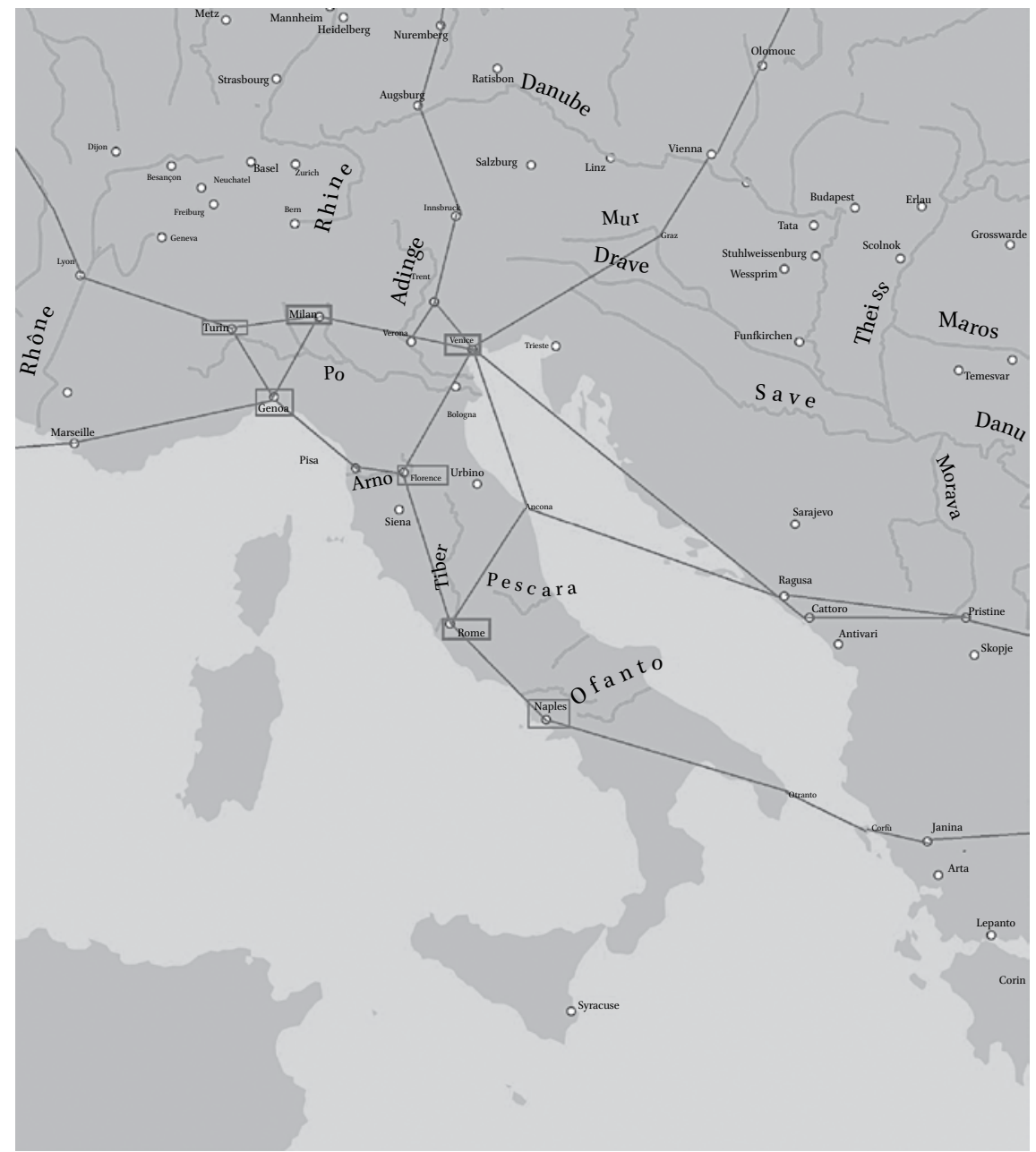

FIGURE 2.1 The nodes in the flows of information across Italy

how it worked. It was in 1608 that Ottavio Codogno, the Milanese deputy postmaster general, published his highly popular guide to the postal services that went through several reprints during that century. Though focused on Europe, it extended to the entire known world, describing a network that allowed people to send and receive correspondence between the far-flung corners of the world. Readers of the guide would discover that if they needed to send a letter from Milan to Goa in India, they would have to ensure that their correspondence reached Lisbon by 20 March, which is when the Portuguese galleons weighed anchor for the Indies.

The nodal points of the postal system automatically became places where news was received and sent on. The organisation of ordinari couriers 


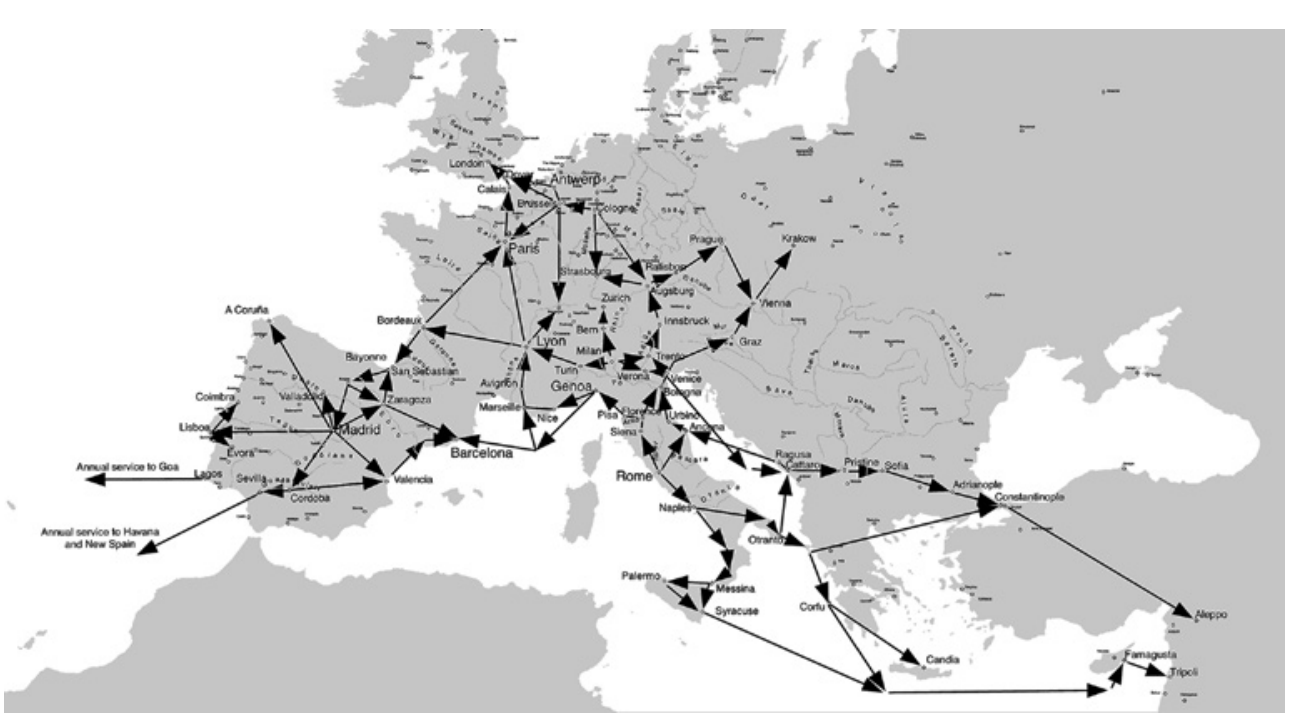

FIGURE 2.2 Ottavio Codogno's scheme of postal routes

and diffusion of information were obviously closely connected. In the sixteenth and seventeenth centuries, for example, the names of postmasters often crop up among the subscribers to news-sheets by the leading gazetteers, suggesting they had taken charge of diffusing and probably even reproducing these newsletters. From the second half of the sixteenth century onwards, the gradual improvement of postal links and greater frequency contributed to the regular publication of handwritten gazettes, which depended upon the arrival of the couriers, making frequent reference to this fact. At the time the standard travel time was 4-5 days from Rome to Venice, 8 days from Rome to Milan, $12-15$ to Vienna and 20-25 to Paris. These were average travel times. Particularly important news, like the death of a pope or of a ruler, was sent via extraordinary couriers who could travel extremely fast. Usually, the news from Paris was published in Venice between 20 and 25 days after the event. But if the piece of news had major political importance, the time differed. In such cases the posts were entrusted to extraordinary couriers, who would stop for nothing. For example, the news of the assassination of Henri IV of France in 1610 reached Venice after only 8 days after the fact and was published in the main handwritten gazette after 15 , when the news was already the subject of public debate. ${ }^{25}$

25 M. Infelise, 'Les mécanismes de l'information: l'arrivée à Venise de la nouvelle de l'assassinat d'Henri IV' in J. Foa, P.-A. Mellet, Le bruit des armes. Mises en formes et 
The relevance of nodes also affected the speed of communications. Travel times depended less on the effective distances of routes than on the ability of couriers and gazetteers to coordinate their activities so that writers could exploit downtime and compile their news-sheets in the intervals between the arrival of one courier and the departure of the next. In fact, news did not necessarily travel along the shortest route nor did shorter routes necessarily guarantee shorter times. For example, it was difficult for the news of Florence to reach Bologna directly; it was more likely that news would be collected in Rome or Venice and then sent to Bologna. Similarly, avvisi from Genoa did not reach Ancona directly, crossing the peninsula from west to east, but would travel via Rome or Venice first. This led to the creation of preferential routes along which information would travel faster due to the better organisation of postal services or existence of political relations favouring the establishment of more efficient lines of communication. In France, news from Marseille took only 11 days to reach the Paris Gazette: a distance of 809 kilometres covered at a rate of 74 kilometres per day. News from Milan, which was in Spanish hands, took 24 days to cover a distance of $85^{\circ}$ kilometres, an average speed of 36 kilometres per day. ${ }^{26}$

The efficiency of transport systems also depended on the political relations between Italian states and other European powers. After 1713, when the Kingdom of Naples passed to the Austrian Habsburgs, it took only 16 days from news from Vienna to be published in the Neapolitan gazette, rather than 22 days as had been the case when Naples was under Spanish rule. It was now possible to cover the 1350 kilometres between the two cities travelling 84 kilometres per day instead of 61 as in the past. At the same time, links between Naples and Spain became weaker.

The postal services had a significant impact upon the total costs of producing news-sheets, even though precise data is not always available. In 1664, Mantua's printed gazette, which was published under the protection of the duke, was compiled using handwritten avvisi arriving every week from Venice, Vienna, Cologne, Brussels, Amsterdam and Augsburg in particular. Subscriptions, including postal fees, ranged from 240 lire for newsletters from Augsburg to 360 lire for those from Brussels and Cologne, accounting for $46.3 \%$ of the total costs; the remainder was made up of costs for printing $(47.4 \%)$ and

désinformations en Europe pendant les guerres de Religion (1560-1610) (Paris: Honoré Champion, 2012), pp. 365-381.

26 Stephane Haffemayer, 'Les gazettes de l'Ancien Régime. Approche quantitative pour l'analyse d'un "espace de l'information"', Histoire et mesure, 12 (1997), pp. 69-91, at 85. 
TABLE 2.1 Estimate of the costs of the Milan Gazette, $1659^{27}$

\begin{tabular}{lrr}
\hline & \multicolumn{1}{l}{$\boldsymbol{1}$} \\
\hline Rent of premise & 900 & 18.9 \\
Compilation & 1500 & 31.5 \\
office worker & 720 & 15.1 \\
postal expenses & 400 & 8.4 \\
delivery in Milan & 72 & 1.5 \\
Supplies & 200 & 4.2 \\
Printing & 800 & 16.8 \\
lighting / heating & 72 & 1.5 \\
Avvisi & 100 & 2.1 \\
Total & 4764 & 100.0 \\
& & \\
\hline
\end{tabular}

paper (6.3\%). ${ }^{28}$ The breakdown of costs for Milan's printed gazette (Table 2.1) is more detailed, and shows that postal expenses could account for $8.4 \%$ of the total investment.

\section{France}

One of the earliest postal services in France was the system of university messengers established in the fourteenth century. The University of Paris's system was particularly extensive, with the student body divided into four 'nations' (three for the various regions of France and one for students from England, Northern Germany and the Low Countries) and messengers assigned to each. ${ }^{29}$ The positions were made more attractive by exempting them from certain taxes. ${ }^{30}$ Similar exemptions were afforded to the postal couriers established in the late fifteenth century under Louis XI.

27 Mario Infelise, Prima dei giornali. Alle origini della pubblica informazione (Rome and Bari: Laterza, 2003), p. 103.

28 Mario Infelise, 'L'origine della gazzetta e l'informazione a Mantova in Antico Regime', in Gazzetta di Mantova. 1664-2014 trecentocinquant'anni avanti (Mantova: Publi Paolini, 2014), pp. 19-24.

29 Suzanne Budelot, Messageries universitaires et messageries royales (Paris: DomatMontchrestien, 1934).

3o Andrew Pettegree, The Invention of News: How the World Came to Know About Itself (London: Yale University Press, 2014), pp. 30-1. 
The postal couriers were set up as a royal service by an Act of 1464, which, it has been suggested, had two original purposes: to keep the king informed of the dauphin's illness, and to allow for better communication to areas where French troops were campaigning. ${ }^{31}$ As in England and Wales, the initial relays were not permanent but ad hoc, put in place for a month at a time with options for extension. The system was designed for the exclusive use of the crown and was, in theory, strictly policed until the late sixteenth century. It was in no sense a public service or a reliable letter-post. ${ }^{32}$ Nevertheless the improvements made by Louis XI to the royal posts provided the infrastructure of the French public posts from when they emerged in the seventeenth century until the advent of the railways.

The early routes to Burgundy, Picardy and Guyenne were established as matters of administrative or military necessity. Later routes to Lyon were important not just because of Lyon's significance but because of its position as a communications hub to the Languedoc, Switzerland, and Italy; the Boulogne road enabled better communication with England, and the Picardy road with Flanders.

In practice, the development of the public postal service in sixteenthcentury France was essentially an extension, often by abuse, of the notional royal monopoly of letter-transport, until the public use of the posts became officially tolerated during the reign of Henri Iv. There is evidence, from an edict issued to prevent the practice in the Languedoc in $155^{\circ}$, of royal messengers supplementing their meagre wages by carrying private letters; a report by a Spanish envoy from 1572 details the same thing among the messengers attached to princes of the blood. (The French crown had also been notably resistant to the extension of the Taxis posts across their territory, although it represented the natural land route between the Habsburg territories in the Low Countries and Spain — see the sections on the Imperial posts above and the Spanish posts below. In the 1560 s and 1570 s special messengers for the Habsburg monarchies passing through France were occasionally attacked by Huguenot bandits with a particular interest in the contents of their messages. ${ }^{33}$ )

One of the key components of the system was its regulatory aspect. The carrying of private letters by the royal messengers was technically forbidden and warrants were periodically issued to that effect; the very fact that reminders had to be issued suggests that they were largely ineffective, however. This was

31 Eugène Vaillé, Histoire générale des Postes françaises, 7 vols. (Paris: Presses Universitaires de France, 1947-55), 2: 24-5.

32 Vaillé, Histoire générale, 2: 36.

33 E. John B. Allen, Post and Courier Service in the Diplomacy of Early Modern Europe (The Hague: Martinus Nijhoff, 1972), pp. 91-2. 
also manifested in the monopoly on horse-hire granted to local postmasters and periodically renewed, along with exemption from various duties as part of their compensation (their wages by themselves were relatively insignificant; and when the Crown ceased to be able to pay them at all, following France's long wars with the Holy Roman Emperor Charles V, Catherine de Medici', the Queen Regent, renewed the horse-hire monopoly in lieu of them). ${ }^{34}$ This privilege was linked to the Crown's interest in monitoring the passage of strangers over French territory, and theoretically made it impossible for a foreigner to pass through the Kingdom unknown, as well as restricting the routes he or she could travel on. ${ }^{35}$ Francis I, who imposed this stricture, was also anxious that there should be no private use of the service, and he forbade the establishment of any rival network. The privilege was essentially unenforceable anywhere except on the great highways, however; the byways, where many of the people who actually hired horses lived, including farmers and smallholders, lay beyond the reach of the authorities in practice. The privilege was also designed to restrict, or at any rate make predictable, the speed at which a person could travel on French roads; a horse hired at the daily rate had to be returned to the renter, and it was the hirer's responsibility to see it done. ${ }^{36}$ The system was liberalised by Henri IV in 1597/8, finally permitting horse-hire for ploughing and barge-pulling as well as travel, and legalising it on the byways as well as the highways.

During the period of illicit use of the royal post by private individuals, and even by the time of Henri IV's assassination in 1610, the network did not cover the whole of France. This was partly a matter of attempts by the Crown to displace the expenses of the service onto the regions, which had been a long struggle. From the 1590s Brittany and the Languedoc, in particular, were resistant; when Brittany was charged for expenditure on the service, the Estates of Brittany responded that no posts had been established in their territory and that it would be dangerous to allow them to be. Brittany was notable for continuing its opposition into the 1620 s, by which time most of the other regional authorities had come around. And indeed the map drawn up of French post routes in 1632 by Nicolas Sanson (see Figure 2.3) shows that Brittany, historically an independent duchy which became subject to the French crown only in 1532, was almost completely disconnected from the primary network.

By 1615 - the point at which Fouquet de la Varane sold his office of Comptroller-General to Pierre d'Almeras - the postal service was organised roughly as follows: Maitres des Postes supplied the actual means of transport,

\footnotetext{
34 Vaillé, Histoire Générale des Postes, 2: 61.

35 Vaillé, Histoire Générale des Postes, 2: 73.

36 Vaillé, Histoire Générale des Postes, 2: 146.
} 


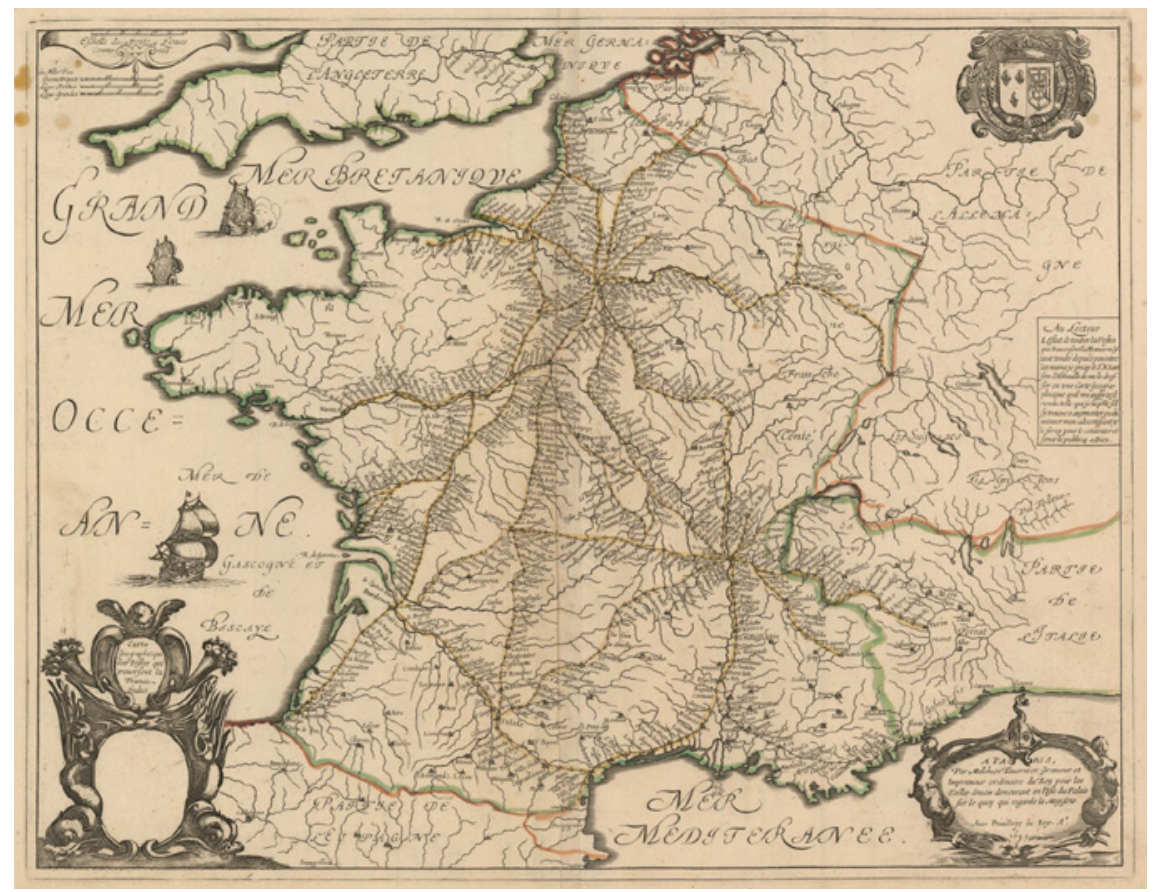

FIGURE 2.3 Nicolas Sanson, Carte géographicque des postes qui trauersent la France. A Paris ... Par Melchior Tauernier ..., 1632. (HMCo1.6723), Historic Maps Collection, Department of Rare Books and Special Collections, Princeton University Library

manning the relay stations and supplying horses; couriers to carry the letters; and commis and distributors to deal with the public, which meant collecting the postage or duties on letters, making sure letters actually reached their private recipients, and so on. This system was fairly attractive for the man in charge, and Vaillé points out that it was in his interest to make sure that the system did not change too much, because the crown and the localities paid for the system's infrastructure and expenses while the Comptroller-General took the profit. If the setup became too costly he risked shaking things up to his own disadvantage.

The creation of the public posts from 1630 changed the management of the postal service, liberating the controleur-général from the oversight of the Grand Ecuyer (master of the royal stables). He was replaced in 1630 by the first Surintendant-général. The regional and local postmasters effectively bought or leased their offices from the Surintendant, as they had formerly done from the Comptroller-General, with the size of the payment depending on the value of the particular post. The inauguration of the post as a public service also saw the introduction of postal tariffs for the first time. These were relatively simple, envisaging only four destinations (Lyon, Toulouse, Bordeaux, Dijon/Macon) 
and three basic rates (for single letters, small packets of up to half an ounce in weight, and large packets of over an ounce). In France as in Britain, postage was payable by the recipient, not the sender.

In addition to the University messengers and the special royal couriers, communal messenger services had begun to be established from the late sixteenth century. These were initially very little disturbed by the establishment of the public posts, which only gradually began to challenge and absorb them as they came to be seen as direct competitors for revenue. Toulouse, for example, employed 14 messengers, 3 providing a dedicated service to Paris and two each to Toulon and Bordeaux, with an implied break between journeys for each messenger. Departures for Paris were fortnightly; the journey would take two weeks, and the messenger would remain in Paris for eight days to distribute and receive letters. On this reckoning the service was notably less efficient than its English equivalent, the carrier system, although it must be admitted that the English carriers had, for the most part, considerably less distance to cover.

In 1672 control was transferred to the Ferme Générale - the revenue-gathering service. Where the previous system had effectively left the revenue of the postal service in the hands of the people who actually ran it, the Ferme guaranteed a certain annual payment to the Crown's treasury. The level of this was renegotiated every time a new Intendant was appointed, and the monarch could (and on several occasions did) displace the incumbent if he saw an opportunity for better terms.

\section{International Post}

Philip the Fair of Burgundy attempted to extend the Habsburg Taxis posts to his French territories for the first time in 1504; Charles V issued a similar order in 1516 three years before becoming Holy Roman Emperor, although he specified that the route was to be established only with the permission of the French crown. ${ }^{37}$ Francis I also created permanent routes to Switzerland and northwest Italy, as well as regular courier services to Rome and Venice in the midsixteenth century. For the most part, however, organised international correspondence went via the Court's special messengers and was chiefly concerned with the specifics of foreign policy and affairs of state. Their privileged status, their proximity to the Court, and the fact that they could be brought to deliver other letters besides those the court had given them in charge gave them visibility; and Vaillé notes that diplomats would interrogate them for the latest news. The Venetian ambassador in France wrote to Venice in 1512 to complain of a messenger who went about announcing the news he was 
carrying while en route; a grave breach of discretion, but one which demonstrates their potential importance in the dissemination of news and not just the delivery of diplomatic messages.

The creation of a public letter-post wrought fundamental changes in the system; partly as the Comptroller-General endeavoured to bring international letter-traffic and the potential for financial gain that went with it under his own control. In particular they challenged the private courier systems organised by foreign merchant communities in France (and centralised, for Swiss and Italian traders, in Lyon). These organisations, by effectively extending edicts already in place for restricting the movement of silver, gold, specie, and uncustomed goods in France, were debarred from operating their own service; in exchange the Comptroller-General was obliged to guarantee a regular service in its place, sending fortnightly couriers to Rome and Venice on the first and fifteenth of each month, with two more leaving Rome for Genoa and Lyon on the same days. ${ }^{38}$ With other states the system gradually became more integrated, with each jurisdiction taking up the transportation of letters within its own territory; earlier in the sixteenth century the monarch faced a choice between employing his own messengers for the entirety of the journey to London (for instance) or entrusting his letters to the English king's posts, a potentially risky approach. ${ }^{39}$

Just as the distinctive outlines of the English postal network are determined to some extent by its island position, France's are determined by the way in which its territory is interposed in the middle of the Habsburg empire. The existence of the Taxis postal service effectively meant that there was little need for France to establish its own postal services for communication with Spain, Flanders, or the German lands. These routes were complex, and subject to local shifts occasioned by rebellions, changing alliances, outright disruption during the Thirty Years War, and were eventually displaced as the primary means of transmission across French territory by the establishment of the public letter-post and by Fouquet de la Varane's attempts to bring this properly under his control. ${ }^{40}$

\section{Spain}

The working of the mail system in early modern Spain is well understood, but studies have seldom considered the implications of this postal system in the

\footnotetext{
38 Vaillé, Histoire Générale des Postes, 2: 296-8.

39 Vaillé, Histoire Générale des Postes, 2: 339-42.

40 Vaillé, Histoire Générale des Postes, 2: 344-73.
} 
development of a national news market. ${ }^{41}$ How-in its more material dimension-did news travel to and from Spain?

To begin with, news-in the form of cartas de aviso (handwritten newsletters), as well as printed gazetas — circulated through the system of estafetas or posts established by the king for the use of his subjects. Alongside this, there existed a royal mail system exclusively used by the authorities, and a further postal infrastructure employing private carriers and used by all sorts of people. This is why we often read in news pamphlets and gazettes that news had arrived through 'el ordinario' — the ordinary mail system—or

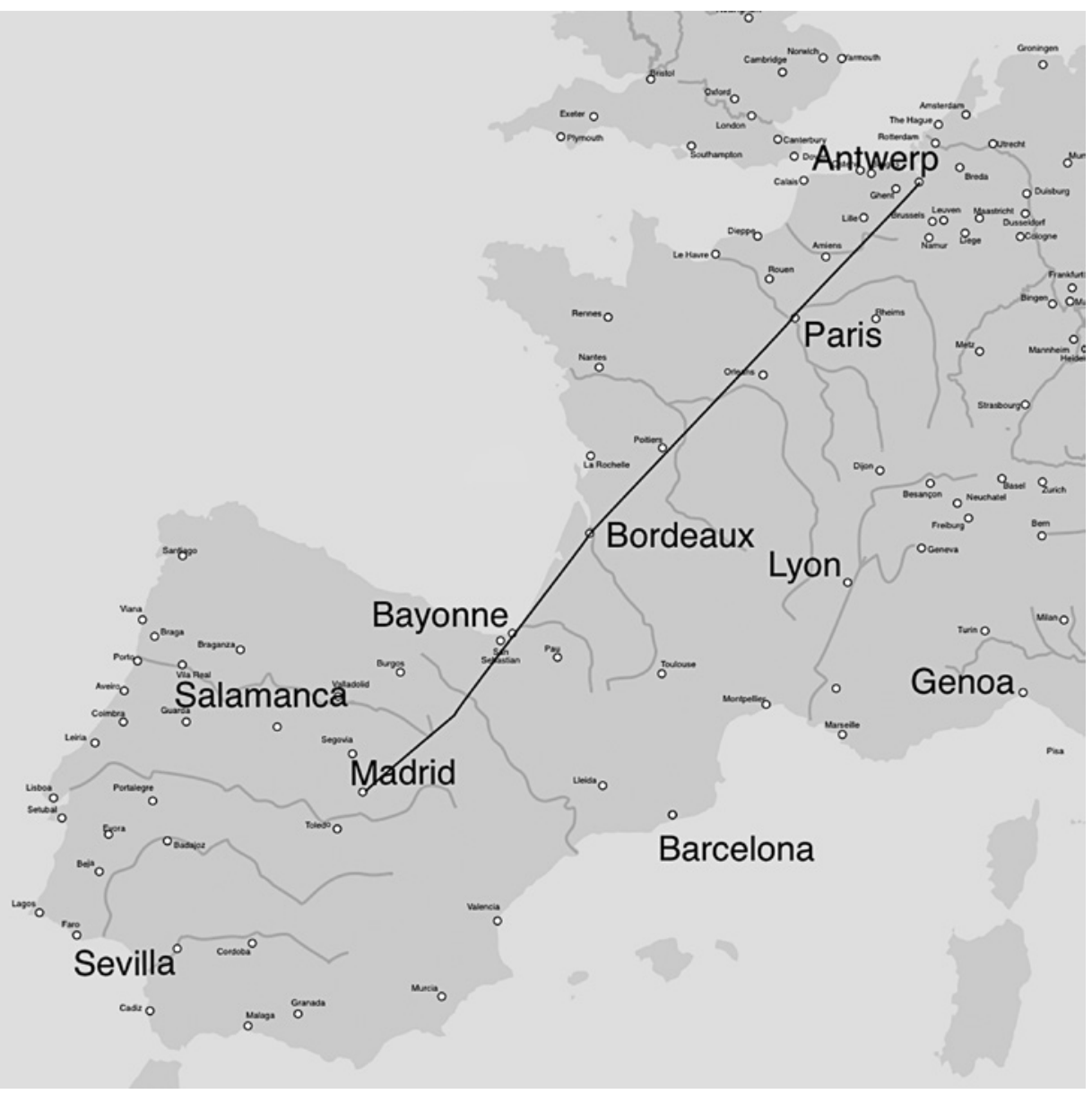

FIGURE 2.4 Madrid to Antwerp

41 See Montáñez Matilla, María. El correo en la España de los Austrias (Madrid: Consejo Superior de Investigaciones Científicas, 1953); Alonso García, Fernando, El Correo en el 
'el extraordinario' - an extraordinary mail system. This is the same standard division as obtained in many other European jurisdictions.

The official Spanish mail system was established from 1580 onwards by the Taxis family; but, here as elsewhere in Europe, some other international mail systems - mainly the one established in Antwerp—were able to compete with it for efficiency and speed. In any case, these systems provided two main routes linking Spain with the rest of Europe: first, the route that joined the capital of the kingdom - Valladolid or Madrid - with Antwerp via Bordeaux and Paris; secondly, the route that linked the capital with Rome via Lyon (see Figure 2.5). Nevertheless, to reach this latter point, an alternative route started from Barcelona and reached Rome by the sea, via Genoa (see Figure 2.6).

Meanwhile, within in the Iberian Peninsula, the main route started in Irún, close to the French border, and reached Vitoria, Burgos, Valladolid,

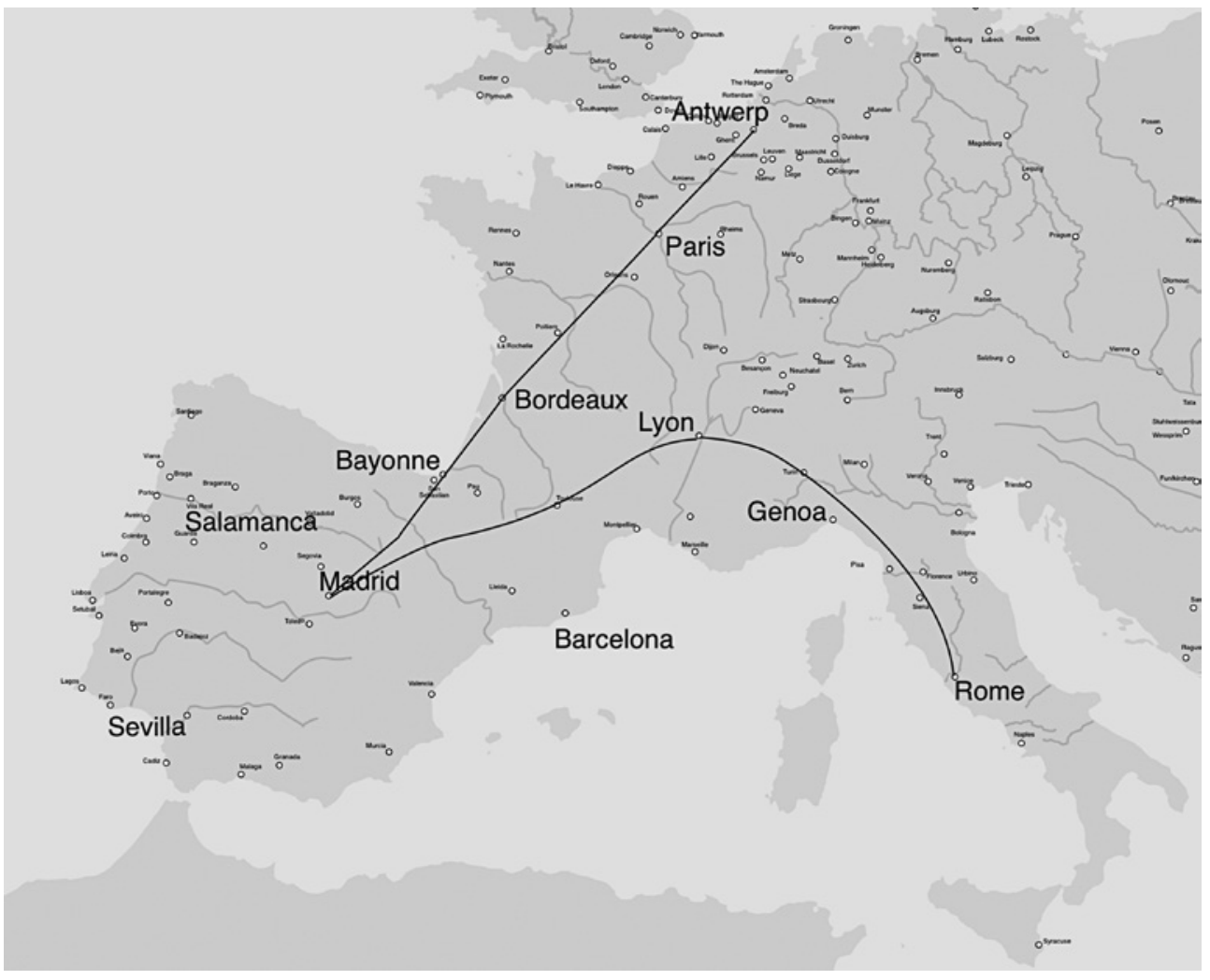

FIGURE 2.5 Main postal routes linking Spain with the rest of Europe

Renacimiento Europeo. Estudio Postal del Archivo Simón Ruiz (1553-1630) (Madrid: Fundación Museo de las Ferias, 2004). 


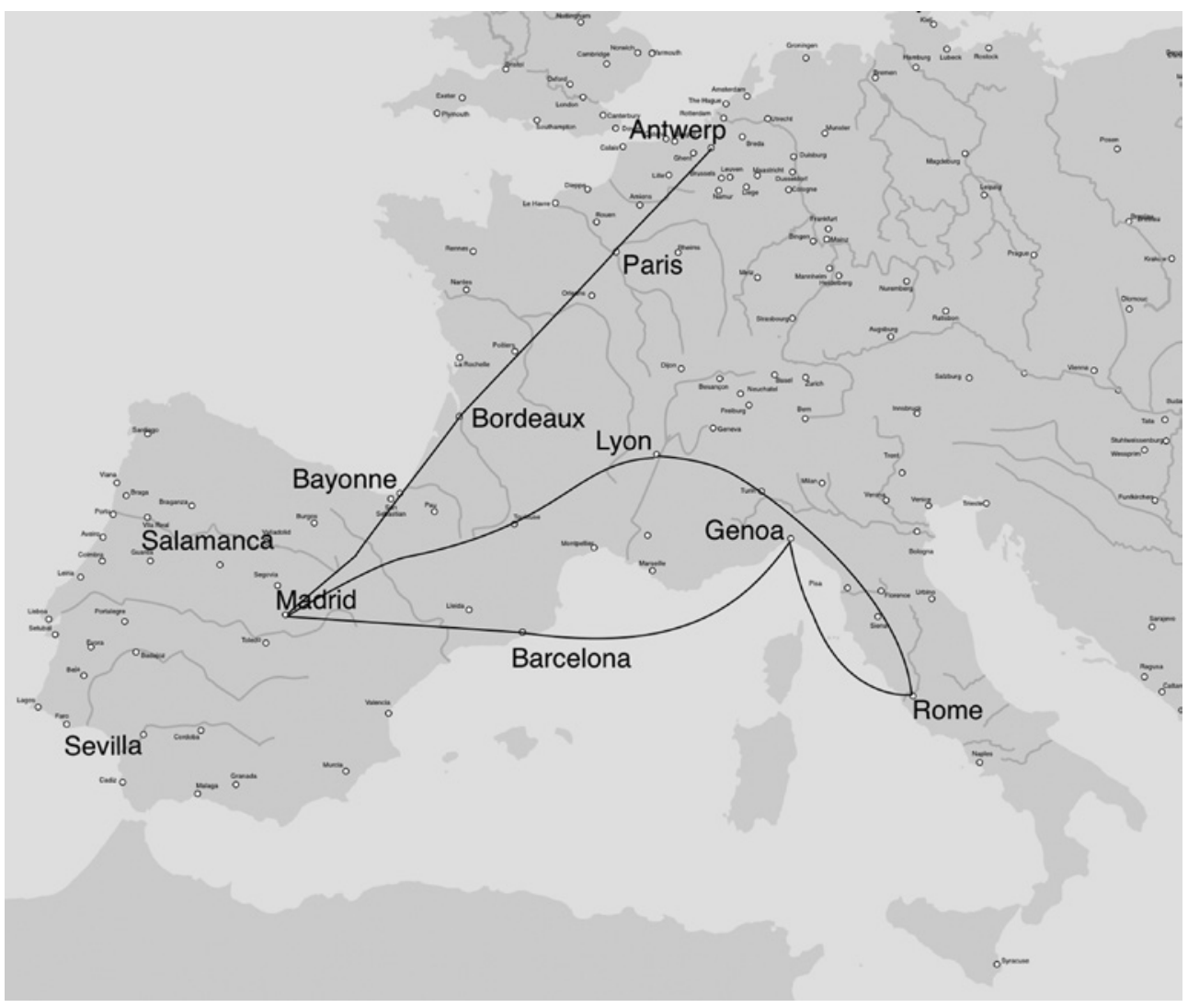

FIGURE 2.6 The alternative sea route from Madrid to Rome, via Barcelona and Genoa

Medina del Campo and Madrid, and, from there, the rest of the regional capitals such as Barcelona, Lisbon and Seville. Prior to the eighteenth century, communication between Madrid and other towns in the Kingdom, Seville for instance, used to be done through mail on a weekly basis, weather permitting (see Figure 2.7).

European and Spanish mail to and from the Indies (or the Americas) was collected in Seville, the only port licensed to do so. The 'Correo Mayor de Indias' - the official postmaster in the Americas - who resided in Lima, Perú, had leased this part of his business to successive lieutenants of the Casa de Contratación established in Seville: this was because from such a distance he was unable to manage the onward distribution of American mails within Spanish territories in Europe.

Despite the speed with which postal system was established in Habsburg kingdoms, Spain generally fell outside the mainstream conduits of the 


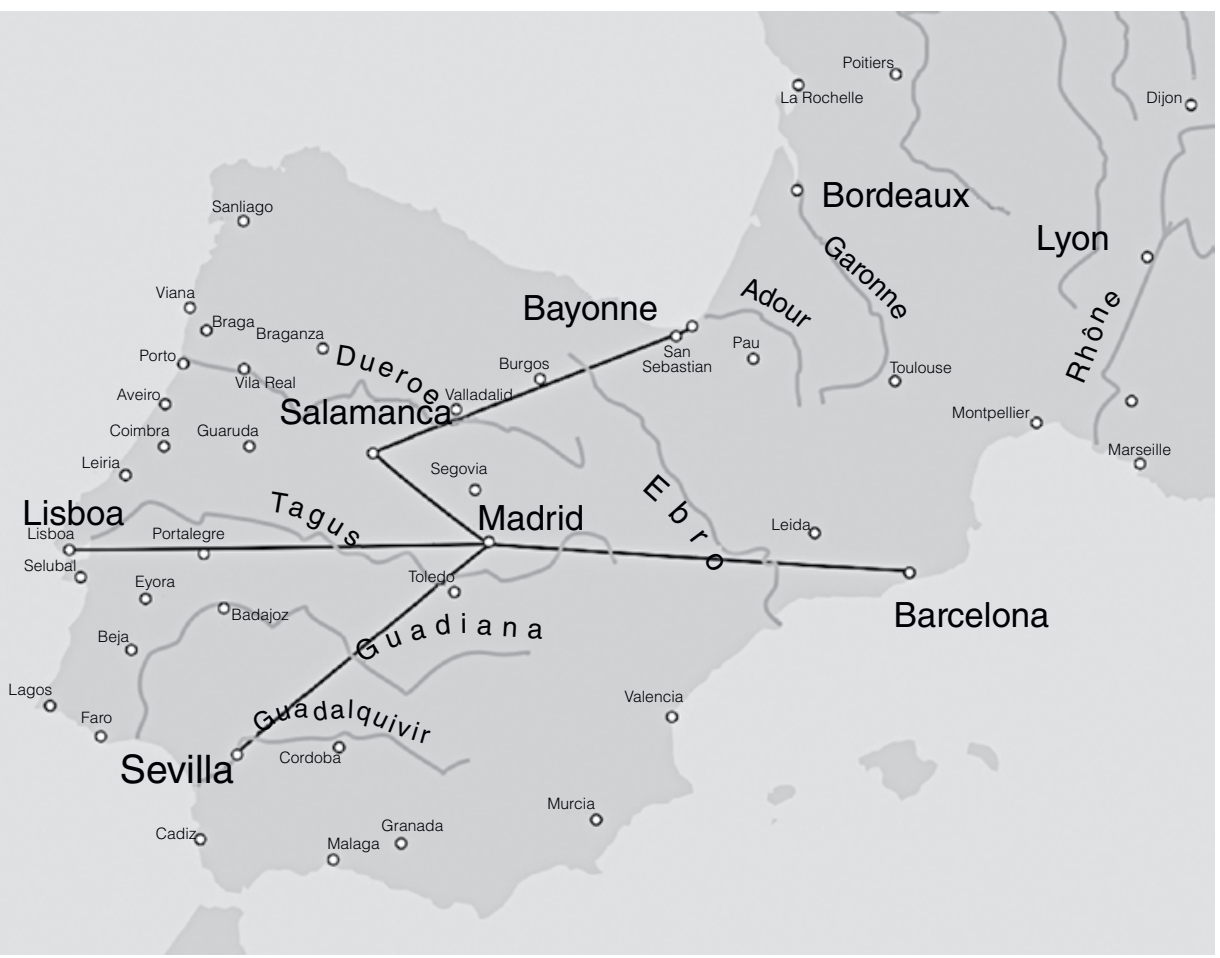

FIGURE 2.7 Main postal routes within the Iberian peninsula

European news network. Paul Arblaster has remarked that the 'reintegration' of Spain within large international postal networks only occurred after 1650 . Stéphane Haffemayer points out that Spain sent out no news on its own account before 1659. This implies that, before that date, information about Spain that reached European newspapers arrived through other intermediaries, mostly Italian, French and Flemish, and with some delay when compared with communication from other peripheral lands. ${ }^{42}$

Given the dates, the reason for the marginal situation, indeed even the partial failure of the postal and communicative flow, could be blamed on the position of Spain at the beginning of the Thirty Years War - which is considered by some scholars as a true starting point for journalistic activities in Europe. Postal traffic was seriously hindered by a French boycott, which followed the

42 Arblaster, 'Post, Newsletters, Newspapers', pp. 21-36. Stéphane Haffemayer, 'La géographie de l'information dans la Gazette de Renaudot de 1647 à 1663', in Gazettes et information politique sous l'Ancien Régime, ed. Henri Duranton and Pierre Rétat (Saint-Étienne: Publictions dei'Université Saint-Étienne, 1999), pp. 21-9. 
outbreak of the war officially declared some years after. The carriers had to look for alternative routes avoiding French soil (although the disruption to overland postal traffic through France was never total, with news and other letters and merchandise to and from Spain occasionally crossing France, even during wartime). Between 1689 and 1815, for instance, carrier boats sailed from La Coruña (in the North coast of the peninsula) to Falmouth in England. For all the perils of the Northern seas, this route made it possible to circumvent French territory. ${ }^{43}$

As the news traffic depended on the mail system, it was seriously harmed by the inconveniences of Franco-Spanish war (1635-59). But news found other ways to get itself broadcast. As early modern often dealt with military and diplomatic matters, they often travelled with troops and ambassadors throughout Europe. News pamphlets and gazettes included sometimes blunt references to this fact, with the line 'desde el campo' indicating that they came straight from a military dispatch written on the battlefield.

The zeal of Spanish Habsburgs was remarkable too, and they strongly devoted themselves to maintaining law and order on the 'caminos', the roads on which their armies travelled. The defense of the 'Spanish roads' that, starting from Mediterranean coast, via Genoa and the Lower Palatinate, communicated between the two large strategic dominions of Habsburg Spain-the Iberian Peninsula and Flanders - is at the origin of most of their military or diplomatic decisions. But this route also consequently lay between the military targets of the Spain's many enemies in this war, and its closure must have been an obstacle for news circulation, too.

In fact, scholars have pointed out that communication between Spain and Flanders was made, curiously enough, indirectly through Italy. A major reason for this must have been continuous French harassment of Spanish roads and mails, which discouraged shorter and straighter routes.

Having said all the above, the Spanish news market must have been strongly dependent on the Italian market right through the first decades of the seventeenth century, for reasons all related to the communication infrastructure. This gave a communicative advantage and a prominence to cities near Spanish Mediterranean seaports, such as Barcelona and Valencia, places in which journalism was more often practiced than in inland Spain.

We need, therefore, further research which tries to analyze whether the Iberian Peninsula, particularly Spain, lay outside the main news networks, and whether this affected the development of early Spanish journalism. Our

43 Antonio Meijide Pardo, Correos marítimos entre Falmouthy La Coruña (1689-1815) (La Coruña: Librería Arenas, 1966). 
hypothesis is that, before the Spanish-French war declaration in 1635 , Spain was well connected to the rest of Europe through the same routes that served the rest of the European news markets. That is why the emergence of journalism in Spain is concurrent with its appearance in the rest of Europe and adopts very similar formats and genres.

A second hypothesis is that, from the outbreak of the Spanish-French war, Spain was progressively isolated, and that this contributed to the slow development of news communication by comparison with other countries in Western Europe (and that this reason is at least as significant as the one that is more usually given, which always looks to censorship as an explanation for the delay of Spanish journalism).

It is noticeable that the most prolific moments of early journalism in Spain coincide with the period leading up to the outbreak of the Franco-Spanish war, around 1618, and the moments after the end of the same war: the official Gazeta Nueva-published under tacit privilege, and which no doubt might have helped in the ending of the Spanish communicative isolation-appeared in 1661, only three years after the end of the war. Further research may prove the hypothesis or explanations given here, linking the evolution of Spanish journalism to the development of the international mail system.

\section{Portugal}

In Portugal, as in the rest of Europe, the evolution of the postal service was complex, with different elements existing alongside one another well into the seventeenth and even the eighteenth centuries. First, by the coexistence of and, to a certain extent, competition between different systems for distributing messages. This complexity was also present within the royal administration, which granted different privileges to transport messages to specific bodies. Royal monopoly of the 'private' Post was not taken for granted but something that was historically built by different actors, not always following a 'public' interest. As a consequence, it is possible that most representations of postal systems in maps tend to focus, perhaps to a misleading extent, on the royal routes of the post, failing to give us a global picture of an intrinsically heterogeneous system in which the role of almocreves (mule drivers) and correios de pé (foot messengers) remained very important throughout this whole period. ${ }^{44}$

44 For a recent, updated, state of the question, see Margarida Sobral Neto, ed., As Comunicações na Idade Moderna (Lisbon: Fundação Portuguesa das Comunicações, 2005). 


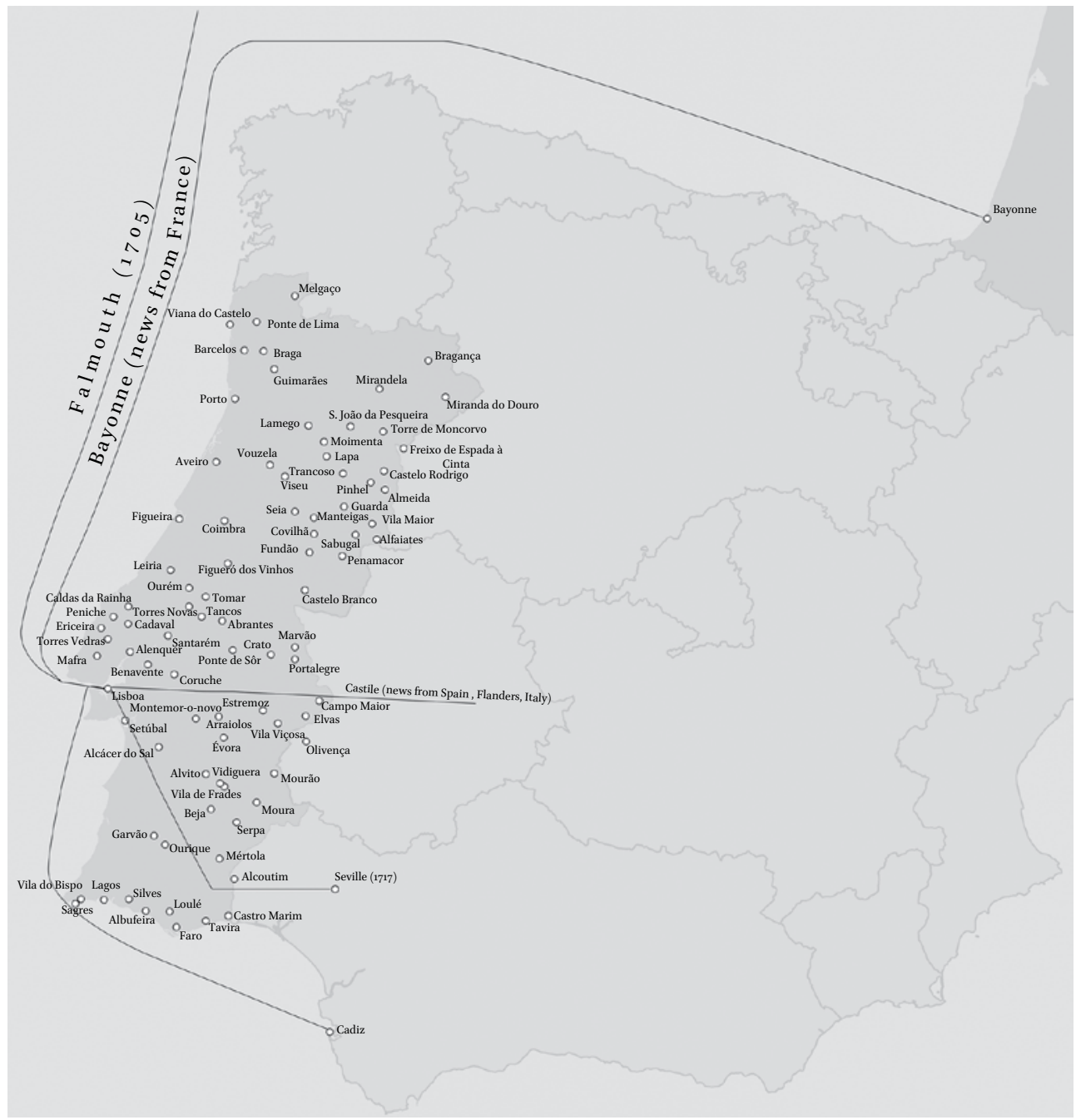

FIGURE 2.8 International news routes into Portugal in 1763, based on João Baptista de Castro's Mappa de Portugal, 1762-3

\section{Origins of the Postal System of the Portuguese Monarchy} $15^{20}$ saw the creation of the royal office of the Correio-mor. Administrated and inherited by private families, the office was incorporated in the crown only in 1797. In the years after 1580 , following the integration of Portugal in the Habsburg monarchy, the two main routes of communication of the early modern period were organised the first connected Lisbon with the main relays of the north-south axis: Coimbra, Aveiro, Porto and Braga. The other main route was the connexion from the capital to Aldeia Galega, to the south of the 
Tagus's bank, with Elvas-Badajoz in the Castillian border, the relay to the postal system of northern Europe, Flanders and Italy.

The office of Correio-mor was sold in 1606 to the Gomes da Mata family (from Elvas, confirming the geographical importance of this nodal point). This family would monopolise and govern the post until the end of the eighteenth century. When the Gomes da Mata took the office, the royal postal networkthe ordinário — worked on a weekly basis between Lisbon and Braga. The jurisdiction of the Correio-mor extended to the maritime post in 1657 (the Indian Ocean excepted), but its role limited itself to fiscal operations of invoice and reception, not the conduction of letters.

As mentioned, alongside the crown other organisations had their own post or messenger services. Of particular note are the hierarchical network of the Church (bishoprics), the University of Coimbra, the Inquisition, and the royal charities (Misericórdias). In many cases the couriers employed by these services travelled on foot. Every institution had its preferred routes and chose the best way to carry messages and orders. ${ }^{45}$

Even though the Crown paid the Correio-mor annually, it also made systematic use of its own, much more rapid, 'extraordinaries': special messengers who travelled day and night, with all the additional costs involved. The Crown could also make use to the Church network, more dense, to obtain information about local life and infrastructures. This dual system, of an ordinary service as well as extraordinary, high-speed couriers for special situations and much more narrowly employed in the royal service, was also found in Venice, in England, in Spain, and in France. Broadly speaking, then, there was a contrast between the relative efficiency of the international mails to and from Lisbon, and the relative slowness of the land routes, especially within Portugal itself.

In the eighteenth century a series of conventions and agreements were signed in order to develop the domestic routes and regularise the international ones. The appearance of a stable weekly Lisbon Gazette (1715) should be seen in relation to the reliability and increased periodicity of such international connections. Some important dates are:

1702: ordinary post service to the Algarve, followed by measures to prevent mule carriers (almocreves) to carry letters.

45 Thus there were more land routes to Spain than shown on the map: for example, the Coimbra Inquisition's communication with Castille depended on the destinationletters via Almeida or Bragança to Valladolid; via Almeida to Murcia; via Valença to Galiza; via Évora to Granada. And there could be messages sent by ship to Coimbra, Porto, etc. 
1705: convention with the English post (via the Falmouth Packet), with an agreement to establish a weekly connection between Falmouth and Lisbon.

1716-18: after the peace following the war of Spanish Succession, postal agreements with Castille in order to facilitate the postal exchanges in the border (Badajoz) and the weekly connection to Lisbon; land postal service to Seville, via Tavira.

Eighteenth century sources also mention the development of alternative maritime routes to the land postal service: mail arrived from France via Bayonne and from Spain via Cadiz. Nevertheless, complaints about the slowness of the post and the inefficiency of the Correio-mor were an enduring topic ("Letters ran as slow from Miranda do Douro [northeastern Portugal] to Lisbon as from Paris to Lisbon", observed one disgruntled observer in 1740 , while the ambassador D. Luis da Cunha offered criticisms of his own, preferring the Dutch model). Proposals were made to incorporate the office into the Crown, in the hope of securing a more efficient administration.

\section{Britain}

Britain (a term that is problematic in this period, as it refers to an archipelago notionally, but not actually in this period, united into a geo-political entity) is an interesting case with respect to the development of postal connections precisely because it is surrounded by water. It exists at the margins or periphery of the wider European network, but is still part of that network, not least because the rest of Europe was interested in news from Britain. Moreover, its connectivity to the European postal system depended on a limited number of nodes; and inside those nodes it had a largely autonomous system. Thus it had its own logistical needs, as well as a distinctive relationship to the mainland.

What were the effects of the isolation of Britain by water, how did this shape the development of post and the cultures surrounding it, and how did it shape the role of news there? The north Atlantic archipelago is not unique in being a group of islands that constitute a geographically and politically semidistinct region of Europe. It may be unique in the imbalance between longterm political and economic influence and its isolation. However, there are ways in which the culture of the archipelago was shaped by geographical circumstance and transport networks; and therefore it makes sense to identify some of its distinctiveness before proceeding with the mechanics of its postal networks. 


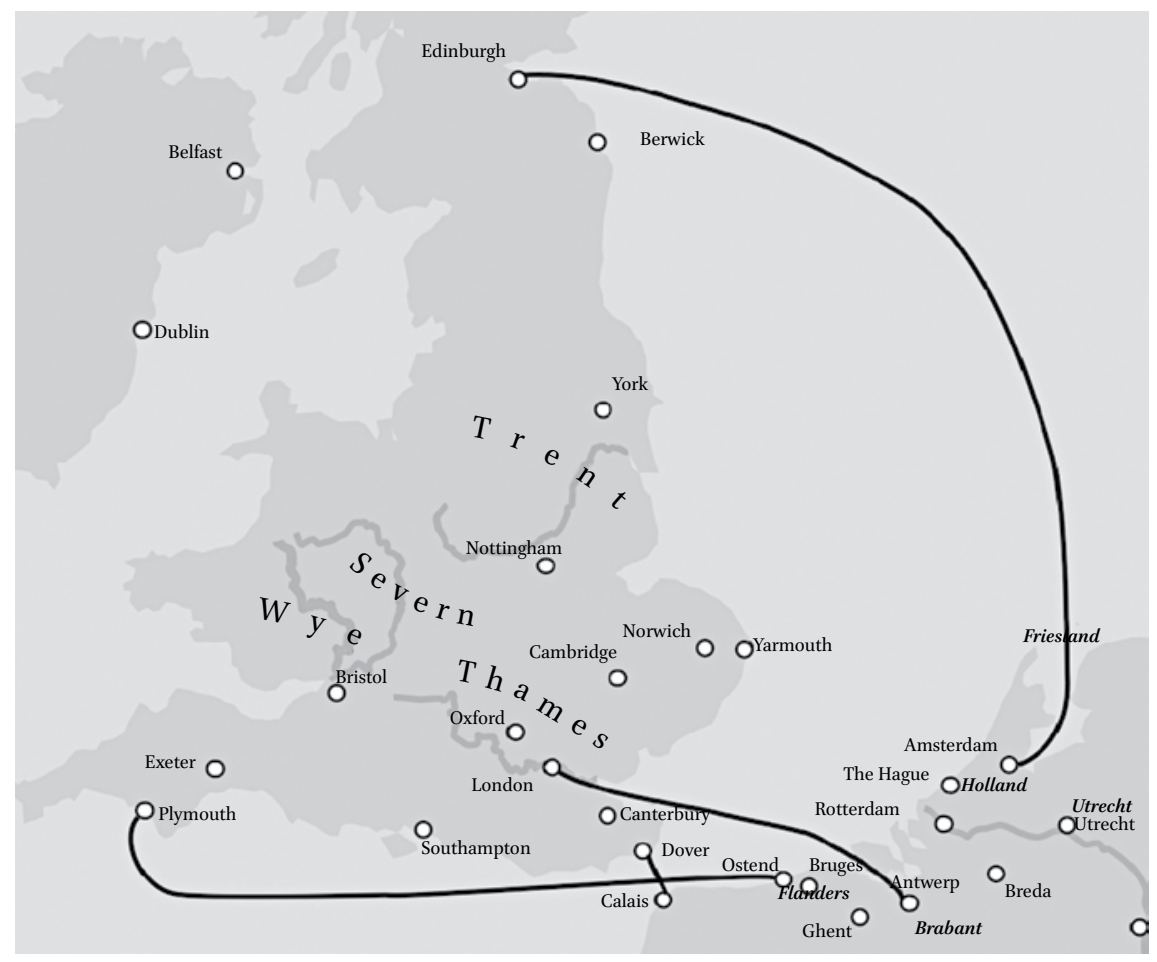

FIGURE 2.9 The water routes for news, showing landfalls at Edinburgh, London, Dover and Plymouth

England - or even, after the union of 1536 , England and Wales, a hendiadys that is often understood though left unspoken-is not and has never been an island. But you would be forgiven for thinking that some of its inhabitants over the centuries had mistaken it for one. Not only was there the problem of the northern neighbour Scotland (the union of the Crowns in 1603 did not prevent war, of course, nor the political union of 1707); but also the Isle of Man with its own parliament; and Ireland, which was an unsettled colony of the English crown with a strong Scottish presence. And there were the territories of northern France governed by the English crown until 1558; which were followed by invasion attempts in 1627-29; and more successfully in 1658 against Dunkirk, which was sold back in 1662. So there were good reasons for not thinking of Britain let alone England as an island. But gradually through the seventeenth century it came to be thought of as one, and the English and British began to identify themselves as islanders.

However, the sea is important to the English imagination, as are boundaries. The model for understanding the geography of seventeenth England was not centre-periphery but through boundaries. Once a year, during Rogation week, 
every child in each English and Welsh parish was required to follow the local priest or curate and 'beat the bounds' of his or her parish. Since 1559 this had been a secular function, undertaken not in imitatio Christi, but in order to know the boundaries of one's parish. Walking around the periphery was how one knew where one belonged. Hence the sea represents where one lives. But it is also a convenient, fast and comfortable, if sometimes terrifying, mode of transport - and with the roads in appalling condition, as British and foreign travellers frequently complained, the sea was frequently preferable to land transport. The growing sense of Britain as an island was not necessarily rooted in xenophobic nationalism ${ }^{46}$ but in how English and Welsh people understood belonging to a place.

This permeable isolation - or peripheralness-also characterised the book trade in Britain, which in turn shaped the postal networks. The book trade was (i) uniquely centralised in London (itself not geographically central), except for a much smaller centre in Edinburgh, and some printing at the universities; (ii) regulated by a commercial body, the Stationers' Company, whose jurisdiction, however, extended only over England and Wales; (iii) more vernacular (and less Latinate) than the print culture of other European countries; (iv) shaped by the lack of indigenous paper production. These characteristics to some extent isolated the British book trade; but they also made it dependent on shipping. While being exceptionally insular, the book trade was also exceptionally dependent on trade, and thus on sea passage. ${ }^{47}$

\section{The Logistics of the Post in Britain}

There were four main modes of transporting written or printed news in early modern England. First, the irregular services provided by packhorses and wagon kept for other purposes and used for communications when circumstances demanded. Both, especially wagons, were notably slow because of poor condition of the roads. As they were irregular their effectiveness and the frequency of use is hard to recover, and they were probably of limited importance in the development of news networks. Secondly, the private retainers or

46 Colin Kidd, British Identities before Nationalism: Ethnicity and Nationhood in the Atlantic World, 1600-180o (Cambridge: Cambridge University Press, 1999); Jonathan Scott, When the Waves Ruled Britannia (Cambridge: Cambridge University Press, 2011); Krishnan Kumar, The Making of English National Identity (Cambridge: Cambridge University Press, 2003).

47 Andrew Pettegree and Matthew Hall, 'The Reformation and the Book: A Reconsideration', Historical Journal, 47 (2004), pp. 785-808; Joad Raymond, 'International News and the Seventeenth-Century English Newspaper', in Not Dead Things: The Dissemination of Popular Print in Britain, Italy, and the Low Countries, 1500-19oo, ed. Roeland Harms, Joad Raymond, Jeroen Salman (Leiden: Brill, 2013), pp. 229-51. 
servants employed by wealthy families and institutions to carry messages over shorter distances. This was evidently not cost-effective, and even in the letters of relatively wealthy families we find the expectation that correspondents will seek out other, common services.

The third mode was the carrier (or 'common carrier'), a system for transporting packets between specific points, with regular periodicity on certain routes. Carriers weekly left London to travel to many parts of the country. The poet, pamphleteer and occasional journalist John Taylor published in 1637 The Carriers Cosmographie, a manual facilitating the use of carriers in Britain, indicating their destinations and times and places of departure. Its alphabetical organisation (by places of destination) serves to provide the reader with an early reference work; it then indicates the inn and day of departure. The full title is as suggestive as the text itself is practical:

The Carriers Cosmographie. or A Briefe Relation, of The Innes, Ordinaries, Hosteries, and other lodgings in, and neere London, where the Carriers, Waggons, Foote-posts and Higglers, doe usually come, from any parts, to townes, shires and countries [meaning counties], of the Kingdomes of England, Principality of Wales, as also from the Kingdomes of Scotland and Ireland. With nomination of what daies of the weeke they doe come to London, and on what daies they returne, whereby all sorts of people may finde direction how to receive, or send, goods or letters, unto such placed as their occasions may require. As also, Where the Ships, Hoighs, Barkes, Tiltboats, Barges and wherries, do usually attend to Carry Passengers, and Goods to the coast Townes of England, Scotland, Ireland, or the Netherlands; and where the Barges and Boats are ordinarily to bee had that goe up the River of Thames westward from London. ${ }^{48}$

Printing this information as an inexpensive, commercial pamphlet suggests a perceived expansion in communications, and a widening demand for postal services in the years prior to the civil war. And it was a changing, developing service: Taylor published a new, briefer guide around $1642 .{ }^{49}$ Even Taylor, not given to modesty, admitted that his information was patchy, so his guide can serve as a pessimistic picture of the minimum services available. Though not comprehensive it is nonetheless extensive. Taylor identified carriers conveying goods to most parts of England, and indicated how packages could be then

48 There is a study of Taylor by Bernard Capp: The World of John Taylor the Water-Poet (Oxford: Clarendon Press, 1994). 
forwarded to Scotland and Wales. Ireland obviously represented different circumstances, and it is difficult to gauge in what quantities books were distributed there in the 1640s. The areas immediately surrounding London were predictably the best served, but Taylor also indicated local concentrations in Yorkshire, Gloucestershire and Dorset. His promotion of his book is suggestive, both of expansive geography and of the particularities of the English regions:

if a man at Constantinople or some other remote part or Region shall chance to send a letter to his parents, master, or friends that dwell at Nottingham, Derby, Shrewsbury, Exeter, or any other towne in England; then this booke will give instructions where the Carriers doe lodge that may convey the said letter, which could not easily be done without it: for there are not many that by hart of memory can tell suddenly where and when every carrier is to be found. I have (for the ease of the Reader \& the speedier finding out of every townes name, to which any one would send, or from whence they would receive[)], set them downe by way of Alphabet $[\ldots]^{50}$

Taylor also refers (in the guidance that concludes the pamphlet) to the post service available via Thomas Witherings (more on him below): 'All those that will send letters to the most parts of the habitable world, or to any parts of our King of Great Britaines Dominions, let them repaire to the Generall PostMaster Thomas Withering at his house in Sherburne Lane, neere Abchurch'.51 The frequency with which place names appear in Taylor's text may not be a straightforward indicator of the geographical density of the services to particular regions, but Taylor does show that there were means of distributing letters, and that these means were relatively easy to access. Speeds were slow, however: Carriers travelled at between 20 and 24 old English miles per day (statute miles, established in 1593, were the modern length of 1760 yards, or $1.61 \mathrm{~km}$; old English miles were about $30 \%$ longer).

I will focus on the fourth mode of sending packets and letters: the post. This was arguably the most significant because swifter and cheaper. The royal post system in England and Scotland was essentially modelled on the Roman post

$50 \quad$ John Taylor, The Carriers Cosmographie (London, 1637), sig. A3r. Though organised as a reference work, it relied on some geographical knowledge. See also Michael Frearson, 'The distribution and readership of London corantos in the 1620s' in Robin Myers and Michael Harris, eds., Serials and their Readers, 1620-1914 (Winchester: St Paul's Bibliographies, 1993), pp. 1-25, at 13-15.

$5^{1}$ Taylor, Carriers Cosmographie, sig. C4v. 
system, the cursus publicus. A 'King's Post' first appeared in the 1480s, under Edward IV and Richard III, though some semi-formalised system had been emerging for about a century. The service was significantly developed and improved under the Tudors, and Brian Tuke was formally granted the title 'Master of Posts', recognising an office that had existed for years, in $1517 .{ }^{52}$

In the sixteenth century, there were four main postal roads in England, the longest terminating in Scotland; they were expanded to six through the early seventeenth century. These were not identical with the major mercantile routes. On these roads were staging posts every 10-12 miles. At each a postmaster was required to have horses ready for conveying royal messages; the remuneration for so doing - a penny a mile per job, doubled to two pence and then reduced to three half pence under Elizabeth, then increasing to two shillings and five pence per mile in 1635 - was not enough to cover the costs, at least not at the level of service required. ${ }^{53}$ In a way this was a form of regional taxation. The royal prerogative meant that the crown had the right to use the goods of any subject in return for a payment that the crown determined. With the appointment of postmaster and the creation of a formal postal system, the king no longer used his subjects' horses, but required his subjects to provide a man with a horse. In return he paid a punitively low rate. However, a profit could be made from 'by letters'-private persons could pay for the service, though their communications would have to be set aside for any official business. In other words, the royal post was a loss-making business that relied on private enterprise to subsidise it; and it was a de facto monopoly.

The first two roads to be established with permanent staging posts - until then stages were ad hoc-were the great north road to Edinburgh, and the Dover road linking the kingdom with France. The year 1512 saw the semi-formal appointment of Sir Brian Tuke as the first postmaster, followed in 1514 by the establishment of a mercantile postal system. From 1555 to 1600 , and especially in the last two decades of the sixteenth century, a series of parliamentary acts were passed aimed at improving the condition and maintenance of the roads. Permanent staging posts on the Bristol, Plymouth and Holyhead roads were established in the 1590s, in response to the military threat from Spain and the Irish rebellion; branches were established to the west midlands from the Holyhead road, where the weapons used by English forces in Ireland were

\footnotetext{
52 Duncan Campbell-Smith, Masters of the Post: The Authorized History of the Royal Mail (London: Allen Lane, 2011), pp. 7-9.

53 Brian Austen, English Provincial Posts, 1633-1840: A Study Based on Kent examples (London: Phillimore, 1978), pp. 1-13; Campbell-Smith, Masters of the Post, pp. 11-12.
} 


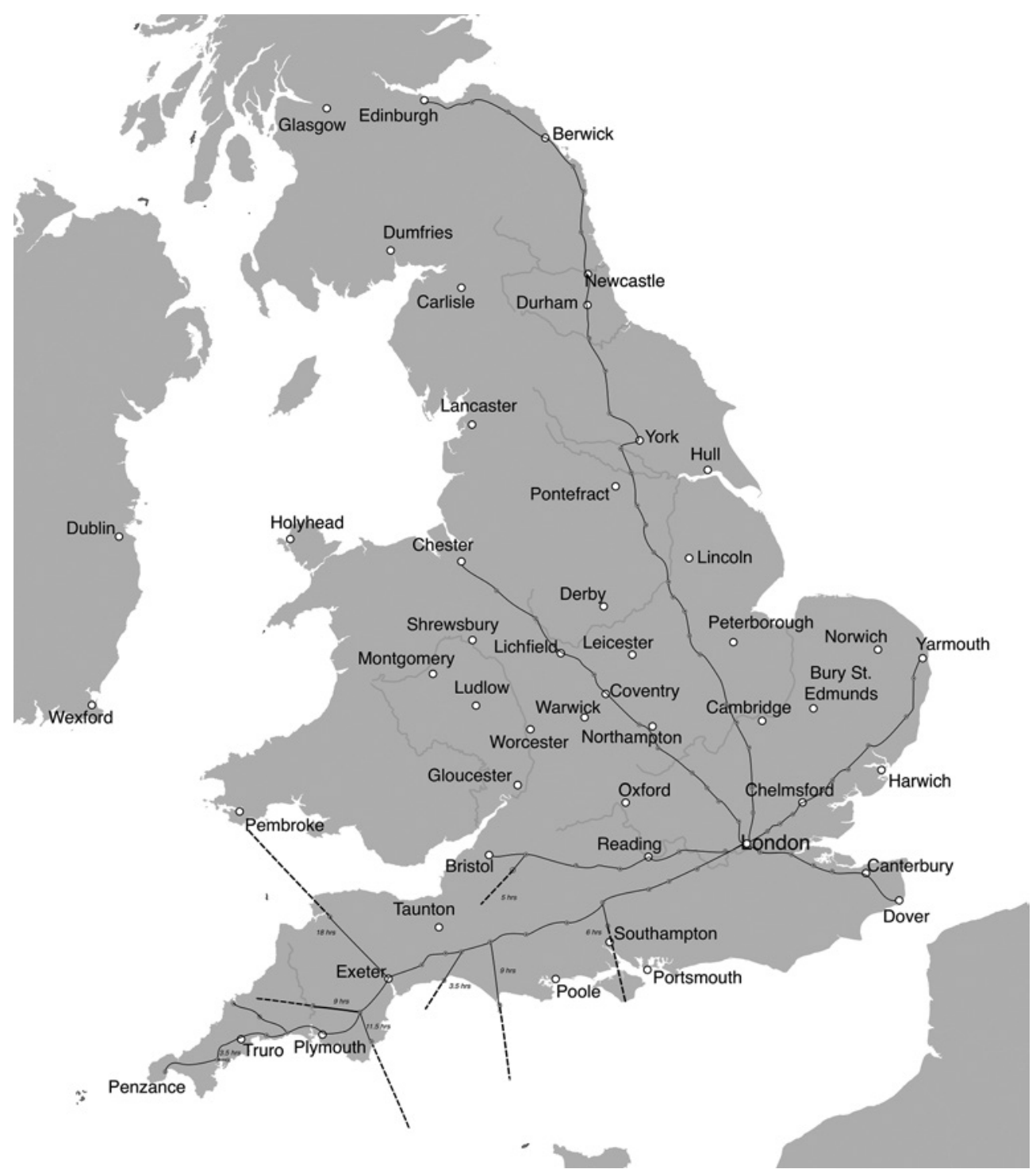

FIGURE 2.10 Post Roads in England, Scotland and Wales, c. 1675 
manufactured. Under Elizabeth the post was also tacitly opened to private customers. ${ }^{54}$ This changed the enterprise from being a financial liability to a potentially lucrative one.

In 1603 the newly-crowned James I of England issued Orders for the Posts of our Realmes, and for all men to observe and obey in the speedy carriage of Packets, directed for our affaires, reviving and renewing previous orders. These stipulated the keeping of horses and means of carriage (cotton-lined leather bags); that each post must be despatched within a quarter of an hour of receipt; the keeping of precise records about packages sent (which, if they were kept and had survived, would be very revealing to the historian); and that the minimum speed of conveyance should be seven miles per hour, reduced to five miles per hour in winter ( 8 and $11.2 \mathrm{kph}$ ). These speeds were seldom achieved. The Orders were most precise about the limitation of the post for official use:

Every Post thus furnished shall at all houres receive and cary, or send away, all Packets or Letters brought unto him, directed for Our special affaires, dated on the outside, with the time and place of their first delivery, and subscribed by the hands of our Principall Secretaries, and Master and Comptroller general of the Postes: And for matters of the Navy, or to the Maritime Forts upon the Sea coast, or principal Port Townes, by our Admirall of England: For matters of the Cinque Ports, by our Warden: For matters of Scotland, by our Treasurer and Secretary of Scotland: And for Ireland, by our Lieutenant of the L. Mountjoy, Or addressed to them in the proper business of their places, or to the body of our Counsell, from what persons or places whatsoever: Of whose names, and addresse only, the Posts shall take notice, according to the first Institution, and Originall use of their service, and of none other. ${ }^{55}$

The royal protestations indicate concern over the Elizabethan opening of system up to 'by letters' - either because it made the system inefficient, or, more likely, because it appeared violate crown privilege and secrecy, of which James was peculiarly protective. In 1619 the first postmaster with specific responsibility for foreign parts was appointed, Matthew de Quester (more on him below). In 1635 De Quester's replacement as foreign postmaster, his former deputy

54 Campbell-Smith, Masters of the Post, pp. 15-18.

55 Orders for the Posts (London, 1603). 
Thomas Witherings, was granted a monopoly to run a national postal service, and he implemented a radical series of reforms, systematising the inland post (as the international post had been systematised), and opening the royal mail to the public, fulfilling a process begun under Elizabeth. The mails, which increased in speed, left London weekly on Tuesdays. ${ }^{56}$

This was surely the most significant event in the development of the posts: the shift in the function of the mail from what was officially a royal function, with a tacit permission of public use, to a public function; combined with a greater emphasis on the profit motive as a means of sustaining it (as opposed to the obligation to the crown). Witherings also regularised the rest of the post, as the Dover road was improved..$^{57}$

Thereafter we can observe a pattern of increasing frequency of postal despatches. This is notwithstanding the civil war, which disrupted but did not halt the operation of the service: king and parliament fought for control of the posts, and parliament won control of all but the Western road by $16433^{58}$ In response the king sought in 1644 to establish an alternative post, based in Oxford and Weymouth. In 1649 the Commonwealth introduced a Saturday post, and the Common Council of London its own post to Scotland. Prices were cut substantially in 1650 , and in 1654 a third weekly post was introduced. The same Ordinance ruled that MPs' letters should be free, and, crucially, gave control of the post to the Protectorate's Secretary of State, John Thurloe. The indefatigable Thurloe was also head of the intelligence services. This confirmed the double-face of intelligence. The 'Act for Setling of the Postage of England, Scotland and Ireland' passed in 1657 explicitly recognised this conjunction when it observed that a post office had proved:

the best means, not onely to maintain a certain and constant Intercourse of Trade and Commerce betwixt all the said Places, to the great benefit of the People of these Nations, but also to convey the Publique Dispatches, and to discover and prevent many dangerous, and wicked Designs, which have been, and are daily contrived against the Peace and Welfare of this

$5^{6}$ Kevin Sharpe, 'Thomas Witherings and the Reform of the Foreign Posts, 1632-1640', Historical Research, 57 (1984), pp. 149-65; also J. Crofts, Packhorse, Waggon and Post: Land Carriage and Communications under the Tudors and Stuarts (London: Routledge and Kegan Paul, 1967), p. 101; Campbell-Smith, Masters of the Post, pp. 23-7.

57 Austen, English Provincial Posts, pp. 5-6.

$5^{8}$ Austen, English Provincial Posts, pp. 9-10. 
Commonwealth, the Intelligence whereof cannot well be Communicated, but by Letter of Escript.

Government surveillance, public news and private communication seem interlinked in this Act. The same Act established the first 'general Post Office'. The 1657 Act also fixed a tariff for private posts. When the monarchy was restored in 1660 a General Post Office was established, followed by the Turnpike Act of 1663 which accelerated the improvement of roads. ${ }^{59}$

It has been demonstrated that the speed of the post improved during the sixteenth and seventeenth centuries: very approximately, journey times fell by half or more between $145^{0}$ and $1620 .{ }^{60}$ The invaluable analysis of Mark Brayshay, Philip Harrison and Brian Chalkley, based, on postmasters' endorsements of letters, shows average journey times from London: 80+ hours to Edinburgh, 55 to York, 50 to Plymouth, 40 to Exeter and Chester, 20 to Bristol and around 14.5 hours to Dover (all in the 50 years to 1620). In addition to the increase in speed there was an increase in volume: for example, use of the Kent posts increased from an annual average of 229 packets a year in the period $1566-71$, increasing by $70-80 \%$ in volume every five years or so to 2146 packets annually in $1589 .{ }^{61}$ Of course the main routes could only carry a message so far. They were supplemented by sub-branches. Travel here was slower, not least because roads were poor. However, it has been estimated that most British towns were within 20 or 30 miles of a staging post. ${ }^{62}$ Some large towns maintained municipal posts that provided a means for local distribution. The earliest extant record of such a service indicates that Norwich had one in $1569 .{ }^{63}$

59 An Act for Setling of the Postage of England, Scotland and Ireland (London, 1657); CampbellSmith, Masters of the Post, pp. 30-2; Joad Raymond, The Invention of the Newspaper: English Newsbooks, 1641-1649 (1996; Oxford: Oxford University Press, 2005), pp. 239-40; Herbert Joyce, The History of the Post Office: From its Establishment Down to 1836 (1893), pp. 15-32; Howard Robinson, The British Post Office: A History (Princeton: Princeton University Press, 1948), pp. 23-47.

6o Mark Brayshay, Philip Harrison, and Brian Chalkley, 'Knowledge, Nationhood and Governance: The Speed of the Royal Post in Early-Modern England', Journal of Historical Geography, 24 (1998), pp. 265-88, at 274-5.

61 Mark Brayshay, 'Royal Post-Horse Routes in England and Wales: The Evolution of the Network in the Later-Sixteenth and Early-Seventeenth Centuries', Journal of Historical Geography, 17 (1991), pp. 373-89, at 380.

62 Brayshay, Harrison and Chalkley, 'Knowledge, Nationhood and Governance', p. 269.

63 Campbell-Smith, Masters of the Post, p. 6. 


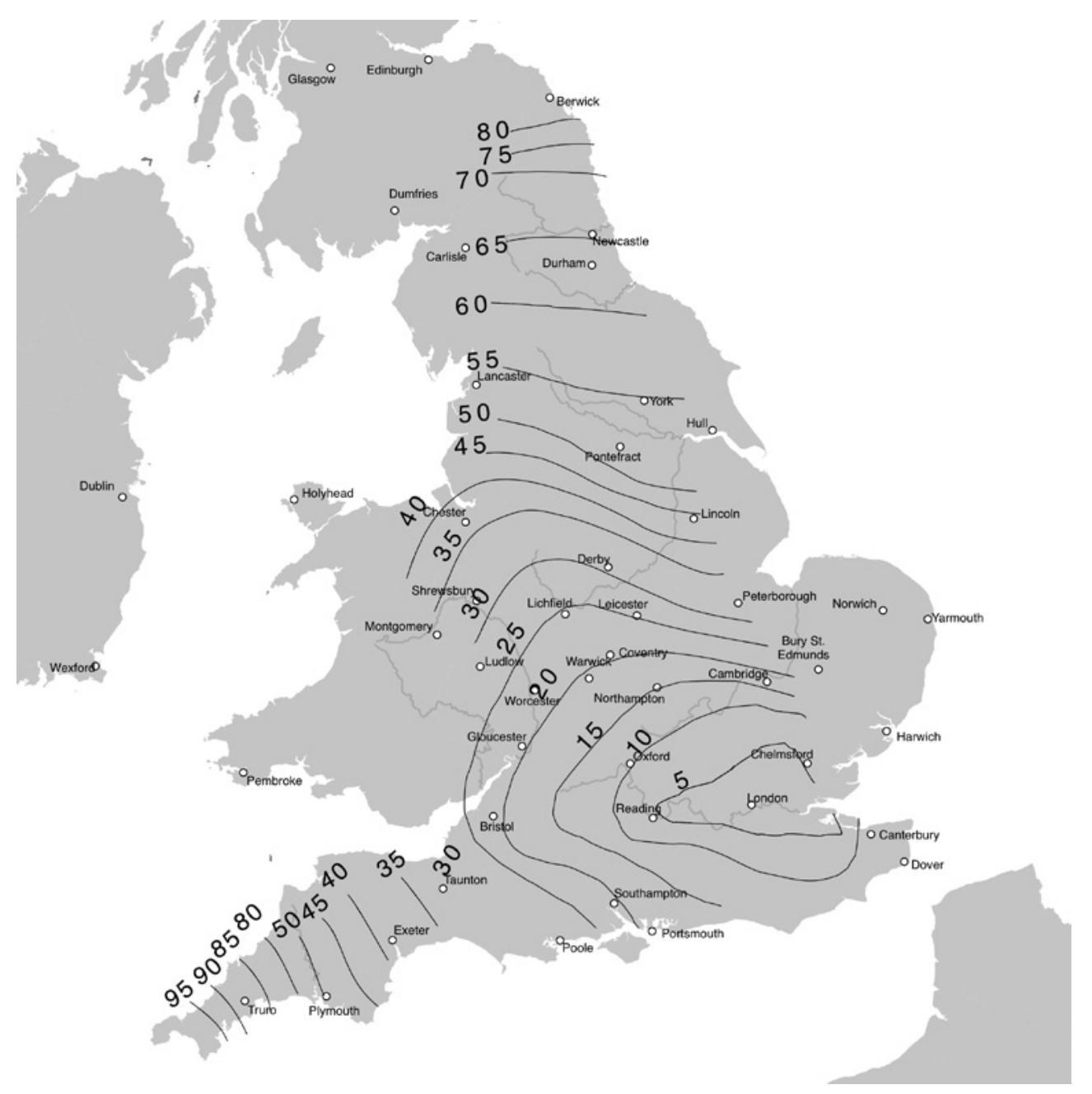

FIGURE 2.11 Average travel times of post along Treasury-funded roads from London, 1570-1620. Times measured in hours, based on postmasters' endorsements. Adapted from Mark Brayshay, Philip Harrison, and Brian Chalkney, 'Knowledge, Nationhood and Governance,' 279

The late sixteenth century also witnessed substantial increases in expenditure on maintaining and improving roads: spending on the Great North road increased from $£ 8333$ to $£ 10743$ in $1566-76$ and $1597-1607$ respectively; payments to postmasters on the Dover road increased by nearly $£ 800$ a decade in consecutive decades up to 1597, reaching £1918 between 1586 and 1597. The most dramatic increases occurred on the Plymouth and Holyhead roads in the first decade of the seventeenth century. These leapt from around $5 \%$ of total 


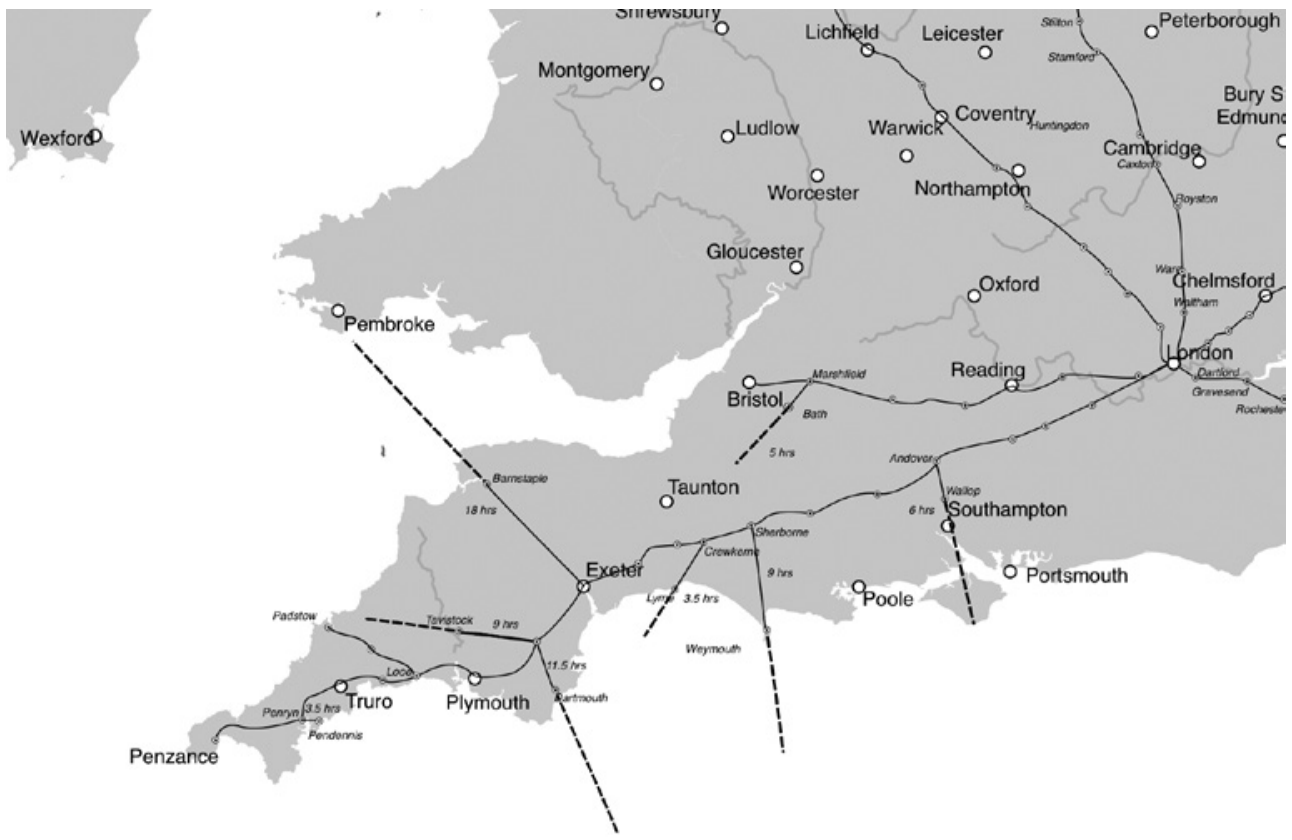

FIGURE 2.12 Post routes to south west England, showing main and subsidiary routes, with travel times to off-route locations. The dotted lines show the actual times (based on postmasters' endorsements) taken to travel to off-route locations by royal post boys, calculated at 5.5 miles per hour $(8.85 \mathrm{~km}$ per hour). Adapted from Brayshay, Harrison and Chalkley, 'Knowledge, Nationhood and Governance,' 283

postal expenditure (1586-97) to over $40 \%(1598-1607) \cdot 64$ The care taken over the roads declined under James VI and I, and he was negligent in paying his postmasters (as indeed he was many of the state's servants).

The costs of posting to the purchaser were as follows: a single letter was carried up to eighty miles $(128.7 \mathrm{~km})$ for two pence, up to 140 miles $(225.3 \mathrm{~km})$ for four pence, and anything further than 140 miles cost sixpence. Postage to Scotland was eight pence. Prices were reduced in 1650; up to 80 miles from London for two pence, three pence to remote parts of England and Wales, four pence to Scotland, and sixpence to Ireland. ${ }^{65}$

The fee of the post service probably did not guarantee door-to-door delivery. It ensured delivery within a certain distance. Extra was paid for the final stage

\footnotetext{
64 Brayshay, 'Royal Post-Horse Routes', pp. 383-4

65 Raymond, Invention, pp. 239-40; Joyce, History of the Post Office, pp. 15-32; Robinson, British Post Office, pp. 23-47; Austen, English Provincial Posts, pp. 5-6.
} 
if it was brought to the recipient's door. A suggestive illustration of this can be found in a bill of disbursements from 1641, which gives the price of 'two printed declaracons' as twopence, and a 'diurnall of parliament Occurrences', evidently a manuscript, as one shilling and sixpence. The purchaser also gave sixpence to the 'post boy' (that is, one who worked under a deputy postmaster, a word first recorded in 1588). ${ }^{66}$

\section{Foreign Post}

A system of international posts had been run by English merchants since the early sixteenth century; prior to that British merchants had benefitted from mercantile communication systems based elsewhere, notably those operated by the Flemish. This system was declared a royal monopoly in 1591, taking the advantage from the Flemish merchants and handing it (temporarily) the Merchant Adventurers' Company (who thereby gained effective control of the Dover road).

James VI and I granted the Flemish Matthew De Quester a patent to run a 'Foreign' post in 1619, effectively providing competition for the inland posts and especially the Dover road. After running this successfully (and despite a challenge to his monopoly mounted in 1627 by the Merchant Adventurers' Company), and making a profit through the private dimension of his business, De Quester was appointed 'Postmaster of England for Foreign Parts' in 1628. De Quester and his son employed 13 messengers: three for ordinary posts to France, six to Antwerp and Middleburg, three for the packet services to France/ Spain and Holland. On Thursday, on 'the tyde that falleth after midnight', letters were sent to Brussels, Heidelberg, Cologne, Frankfurt, Prague, and the Paris-Turin-Madrid route. Letters for the Hague and Holland left on Saturday night or very early on Sunday mornings. ${ }^{67}$

After Witherings' appointment in 1635 , a note was posted on the door of the office for foreign posts which read: 'for way of Antwerp everie friday, for way of France everie wednesday \& for that of Holland everie Saterday al to be in the office before five in the afternoone'.68 The mail was to be in by $5 \mathrm{pm}$, was sent off to Dover at $6 \mathrm{pm}$, from where it took about 14 hours; ${ }^{69}$ packet boats sailed immediately for Calais. Until that point the post took an alleged 8 days to get to Antwerp; this new system was intended to reduce it to 3 days (although, again,

66 TNA, SP 16/493/62; Calendar of State Papers Domestic Series ... 1641-1643 (London: HMSO, 1887), p. 428: the manuscript is more likely to be from 1641 than the stated 1642 ; CampbellSmith, Masters of the Post, 10; OED: post boy, $n$. .

67 Sharpe, 'Thomas Witherings', pp. 149-64.

68 Austen, English Provincial Posts, p. 3.

69 Brayshay, Harrison and Chalkley, 'Knowledge, Nationhood and Governance', p. 276. 
this ideal seems to have been rarely achieved in practice). In 1637 the Thurn und Taxis postmasters stated that under Witherings delivery between London and Antwerp took four days; between London and Milan, seventeen to eighteen days; and between London and Naples, 23 to 24 days. ${ }^{70}$

Before the establishment of the international posts, and continuing alongside them, were ad hoc couriers, paid irregular but often large sums and also travelling irregularly. Like diplomatic services, they constitute part of a news network, though it is difficult to generalise about the nature of their contribution to the shape and form of the network. There were also irregular means of communicating documents in national and international networks. Hence ships returning from Spain and the Levant made landfall at Plymouth ${ }^{71}$ depositing packets, but also collecting them en route to London. Although DoverCalais was officially (from the English point of view) the sole point of postal connectivity with the Continent it was plainly not. Similarly one Samuel Jude was running a private carrying service for merchants between Plymouth and London in $1626 . .^{72}$

\section{Significance of Posts to News Networks}

The post quickly became an integral part of the news infrastructure, the foundation of its operation as a network. While oral exchange must remain the most everyday mode of news communication, the way it worked depended on other modes. The communication of written and printed documents was perceived to be sometimes though not always faster; but where it was not faster, it was understood to be more reliable. Documents confirmed or repudiated rumour. Moreover, news was associated with communication transport; hence 'to tell news after the carrier' was proverbial for a futile action, like shutting the stable doors after the horse had bolted. Carriers told news (and pedlars told gossip). Hence news and postal and carrier networks were fundamentally connected in language and culture more broadly. Post-houses became centres of information in themselves, and in certain jurisdictions, such as Sweden, the postmasters were the designated compilers of official newspapers.

News networks were bound together by conflict — confessional conflict—as well as by trade and community consensus. This caused sensitivity to news at other nodes in the network that bound Europe. ${ }^{73}$ Yet in Britain at least there was little done to transform the news into something that was more evidently confessionally sympathetic. Specifically there seems to have been little adaptation

$70 \quad$ Austen, English Provincial Posts, p. 3; Sharpe, 'Thomas Witherings', p. 160.

71 Crofts, Packhorse, Waggon and Post, p. 97.

72 Crofts, Packhorse, Waggon and Post, p. 98.

73 Arblaster, 'Posts, Newsletters, Newspapers', p. $3^{1}$ 
done in the translation of news: it tended to be neutral. This neutrality - and it is striking that during the 1630 s the English government insisted that translations of news had to be literal - made the practical infrastructure all the more important as an influence on what news was available. ${ }^{74}$

The post had other significance and connotations. First, state centralisation. The increase in traffic and speed, and the systematisation of the postal services, has been associated with state formation or modernisation. Thus Brayshay, Harrison, and Chalkley follow the historian Geoffrey Elton in his account of Tudor state formation: the connection may be overstated. The causes of the development of the postal system were probably at least as much economic as political, and likely to have been driven more by demand, including the demand for news evidenced in other aspects of public life, than by the intentions of successive councils of state.

Secondly, surveillance. Searching posts seems to have been commonplace. It is significant that the meaning of the word 'intelligence' in English communicates news (as digested and interpreted by an editor) and what we would call spying. ${ }^{75}$ The relationship between news and state intelligence took off in the 1580 s under Sir Francis Walsingham, based on practical exigency as much as the emulation of foreign practices. This coincided with the opening of the Royal posts to private customers and the two things were at some level connected. The opening of post was an important element of state intelligence (and, incidentally, ensured that, far from being entirely unguarded in contrast to print, manuscript news was often circumspect). By the mid-seventeenth century the Taxis service had a Black Chamber for the surveillance of postal communications, and it was certainly not alone. Opening letters was extensive during the civil war (ciphers were commonly used in correspondence) and was fundamental to the operation of the government in the 1650s under John Thurloe, who had his own Black Chamber. ${ }^{76}$ The 1657 act clearly established

74 Thomas Archer was reportedly imprisoned for 'making or adding to Corrantoes', BL: Harl. MS 389, fo. 122r; Joad Raymond, Pamphlets and Pamphleteering in Early Modern Britain (Cambridge: Cambridge University Press, 2003), p. 131; Joad Raymond, 'Exporting Impartiality', in Anita Traninger and Kathryn Murphy, eds., The Emergence of Impartiality: Towards a Prehistory of Objectivity (Leiden: Brill, 2014), pp. 141-67.

75 Raymond, Invention, 158-63; cf BL: MS Stowe 176, fo. 3, letter from Ralph Winwood to Sir Thomas Edmunds, 26 March 1616, which uses 'intelligences' as synonymous with both news and spying.

76 Stephen Alford, The Watchers: A Secret History of the Reign of Elizabeth I (London: Allen Lane, 2012); John Cooper, The Queen's Agent: Francis Walsingham at the Court of Elizabeth I (London: Faber, 2012); Nadine Akkerman, 'The Postmistress, the Diplomat, and a Black Chamber?: Alexandrine of Taxis, Sir Balthazar Gerbier and the Power of Postal Control', in 
surveillance as a function (as it implicitly had been prior to 1657). Hence the concern that Quakers expressed about the safe delivery of their letters. ${ }^{77}$ This is subtly different from the fear of interception of letters as they passed between different European states: the state fostered postal networks at the same time as it increased surveillance. And this happened simultaneously with the expansion of public debate, and the increased influence of that debate on national politics. It is further evidence of the very intricate ways that private culture and public culture are interwoven in Britain. News expanded, and as it expanded it was nonetheless governed by notions of secrecy and secrets of state. ${ }^{78}$

\section{Conclusion}

This paradoxical dynamic - between a news culture expanding and developing a rich relationship with its publics (national and transnational), and the tenacious and in some ways increasingly subtle hold of notions of secrecywas integral to news culture in Britain, though signs of similar dynamics can be found in many other European cultures. As further evidence of this we might point to the fact that while the public posts of the late sixteenth and seventeenth centuries emerged from expanding networks originally developed for diplomatic communication and other purposes of statecraft, they did not simply absorb or replace them. European rulers continued to maintain extraordinary private couriers for their diplomatic communications alongside the regularly scheduled postal services; public use of the service rather displaced rulers' original, essentially private conception of it, which then had to be reconfigured outside of the repurposed network. State consciousness of the exploitability of the public posts for purposes of surveillance of people and goods as well as information may have contributed to this perceived need.

Robyn Adams and Rosanna Cox, eds., Diplomacy and Early Modern Culture (Basingstoke: Palgrave, 2011), 172-88; Philip Aubrey, Mr Secretary Thurloe: Cromwell's Secretary of State, 1652-166o (London: Athlone Press, 1990); C.H. Firth, 'Thurloe and the Post Office', English Historical Review, 13 (1898), pp. 527-33.

77 Kate Peters, 'The Dissemination of Quaker Pamphlets in the 165os', in Not Dead Things, ed. Harms, Raymond, and Salman, pp. 217-8.

78 David Zaret, Origins of Democratic Culture: Printing, Petitions, and the Public Sphere in Early-Modern England (Princeton: Princeton University Press, 200o); Filippo de Vivo, Information \& Communication in Venice: Rethinking Early Modern Politics (Oxford: Oxford University Press, 2007). 
The other indispensable point to notice about the emergence of European postal networks is that, although locally variable in their administration and in the speed with which they were established, they were fundamentally transnational in their conception. In Britain, in France, and in the Habsburg lands, the earliest established post routes were to speed communication with other states. The national scope of a postal network was always intended to reach beyond political and linguistic boundaries; and the transnational element always depended on a rich, internal involution. This was one of its strengths in promoting a European news culture that similarly was both local and panEuropean in nature.

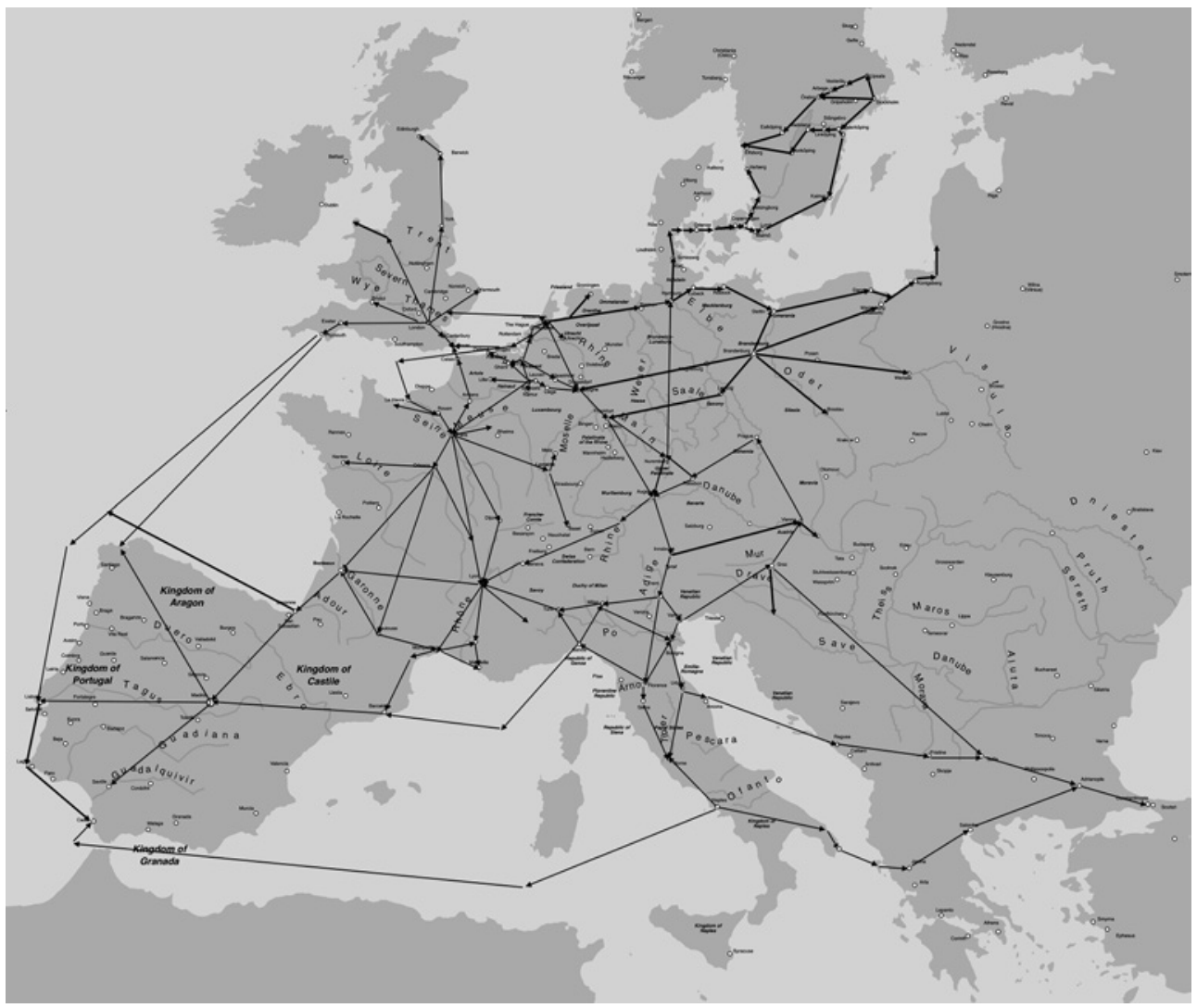

FIGURE 2.13

Sketch map of major European postal routes operating at various times during the sixteenth and seventeenth centuries. Collaboratively compiled, at the Vienna workshop of the News Networks in Early Modern Europe research project, 13/9/12, by Paul Arblaster, Nikolaus Schobesberger, Mario Infelise, André Belo, Carmen Espejo, Joad Raymond and Noah Moxham, with input from Oswald Bauer 
A full picture of the actual flows of news is not yet possible, ${ }^{79}$ but an impression of the spine around which that news flowed can be obtained from a collaboratively drawn map of Europe's postal networks (see Figure 2.13). This can only be impressionistic, because it is neither exhaustive (it represents major routes, and only scheduled travel), and because the actual routes developed and changed over time, but it nonetheless presents an imaginative rendering of a European network of news.

79 See Ch. 4, below. 